\title{
Belirgin Düşey Yük Etkisindeki Betonarme Kirişlerin Çevrimsel Yükler Altındaki Davranıșı Üzerine Bir İnceleme
}

\author{
Cem AYDEMIR 1 \\ Müberra ESER AYDEMİR ${ }^{2}$ \\ Pinar YILDIRIM ${ }^{3}$
}

ÖZ

Bu çalışmada, düşey işletme yükünün betonarme kirişlerin tersinir çevrimsel davranışına etkileri deneysel olarak incelenmiştir. İşletme yükü benzeşimi için kuvvet, deprem yükü benzeşimi için ise çevrimsel ve artan genlikli yer değiştirme kontrollü yükleme geçmişlerinin kullanıldığı deney programında, düşey yük etkisinin belirgin mertebede olmasının plastik mafsal çalışma biçimi üzerinde etkin olduğu gözlenmiştir. Çalışmada, işletme yükü etkisini içeren ve içermeyen tersinir-çevrimsel yüklemeler uygulanarak elde edilen deneysel sonuçlar birbirleriyle mukayese edilmiş ve ayrıca Türk Deprem Yönetmeliği Hasar Sınırı Yaklaşımı kabulleri yardımıyla elde edilen analitik sonuçlarla da karşılaştırılmıştır. Sınırlı sayıda deney numunesiyle yapılan bu karşılaştırmalarda, düşey yük etkisinin belirgin mertebede olduğu ve yön değiştirmeyen plastik mafsal davranışının meydana geldiği deney numunelerinde, Türk Deprem Yönetmeliği'nde tanımlanan analitik Göçme Hasar Sınırı yer değiştirme değerinin oldukça ihtiyatlı kalabildiği tespit edilmiştir.

Anahtar Kelimeler: Hasar sınır durumları, malzeme birim şekil değiştirme sınırları, belirgin düşey yük etkisi, yön değiştirmeyen plastik mafsal.

\section{ABSTRACT \\ An Experimental Research on Hysteretic Behavior of RC Beams under Significant Gravity Loads}

In this study, an experimental research to obtain the effects of significant gravity load on the hysteretic behaviors of RC beams is presented. To this purpose, an experimental program is

\footnotetext{
Not: Bu yaz1

- Yayın Kurulu'na 3 Ekim 2017 günü ulaşmıştır. 29 Ağustos 2018 günü yayımlanmak üzere kabul edilmiştir.

- 31 Mart 2020 gününe kadar tartışmaya açıktır.

- https://doi.org/10.18400/tekderg.341401

1 İstanbul Aydın Üniversitesi, İnşaat Mühendisliği Bölümü, İstanbul - cemaydemir@aydin.edu.tr https://orcid.org/0000-0003-4531-5084

2 İstanbul Aydın Üniversitesi, İnşaat Mühendisliği Bölümü, İstanbul - muberraaydemir@aydin.edu.tr https://orcid.org/0000-0002-4609-4845

3 İstanbul Aydın Üniversitesi, İnşaat Mühendisliği Bölümü, İstanbul - pinaryildirim@aydin.edu.tr https://orcid.org/0000-0002-6667-9365
} 
carried out in which gravity loads are applied by force controlled test procedure whereas cyclic loads are applied by displacement controlled test procedure. It is found from the experimental results that significant gravity load is an effective parameter on plastic hinge mechanism. The experimental results of specimens with and without significant gravity load are compared to each other. Experimentally observed damage states, plastic hinge zones and deformation demands are also compared with the respective values proposed by Turkish Seismic Design Code. The results of the limited number of test specimens show that, the loading procedure with significant gravity load effect leads to the formation of non-reversing plastic hinge and analytical collapse limit given in Turkish Seismic Design Code remains very conservative.

Keywords: Damage limit states, material strain limits, significant gravity load effects, non-reversing plastic hinge.

\section{GİRiş}

Bilindiği gibi betonarme bir yapının -taşıma gücü sınır durumuna göre- tasarımında, yapının kullanım ömrü boyunca güç tükenmesine uğramaması için tasarımda kullanılan tüm büyüklüklerdeki belirsizliklerin kabul edilebilir risk oranlarına çekilmesi gerekir. Bu amaçla, yönetmeliklerde hesaba dâhil bütün büyüklüklerin muhtemel değişimleri dikkate alınarak, kısmî güvenlik katsayıları tanımlanmıştır. Şekil 1'de düşey yük ve deprem etkisindeki bir kat çerçevesi kirişinin mesnet bölgelerinde eğilme momenti tasarım değerlerinin belirlenmesi için esas alınan yük katsayıları (birleşimleri) gösterilmiştir [1].

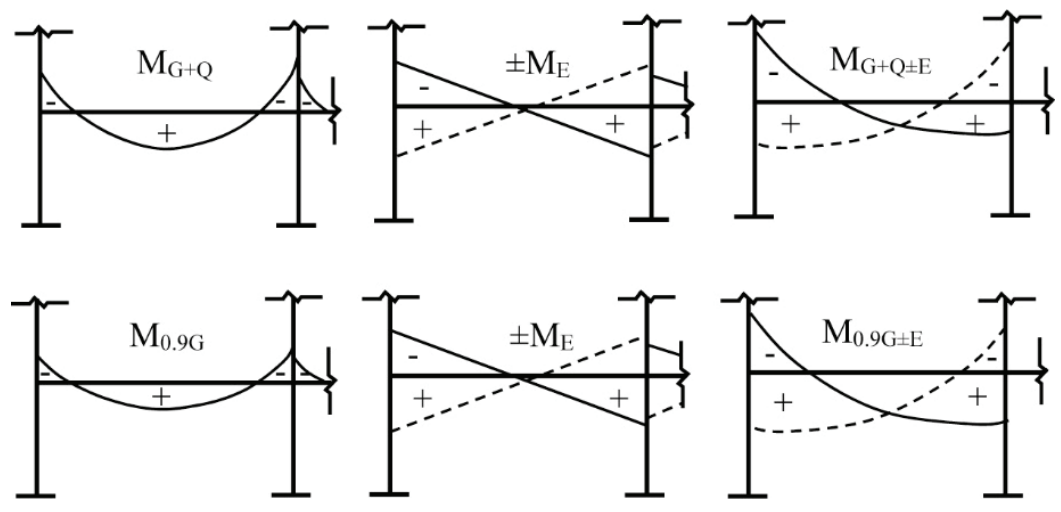

Şekil 1 - Düşey yük ve deprem etkisi altındaki kiriş mesnet bölgelerinde eğilme momenti tasarım değerlerinin belirlenmesi için esas alınan yük birleşimleri [1]

Şekilden de görüleceği üzere, düşey yükler altında tek yönlü eğilmeyle zorlanan kiriş mesnet kesitleri, düşey yük ve deprem yüklerinin ortak etkisi altında çift yönlü eğilmeye maruz kalabilir. Bu çift yönlü eğilme zorlarının, kesitin hem pozitif ve hem de negatif akma momenti kapasitesini aşması durumunda çift yönlü (yön değiştiren), sadece bir doğrultuda kesitin akma momenti üzerinde bir talep meydana getirmesi durumunda ise tek yönlü plastik davranışın (yön değiştirmeyen) söz konusu olacağı söylenebilir. Bir başka ifadeyle; sadece 
düşey yükten kaynaklanan eğilmenin depremli durumdaki tasarım değerine nispetle belirgin mertebede olmasının, kiriş mesnet kesitlerindeki potansiyel plastik mafsalın tek ya da çift yönlü olarak ortaya çıkmasına neden olacağı söylenebilir. Çerçeve kirişlerinin potansiyel hasar bölgelerinde eğilme zorları ve plastik moment kapasitesine göre yapılan bu değerlendirmenin yanında, davranış, kiriş ekseni boyunca kesme kuvvetinin işaret değişimine göre de izlenebilir. Deprem etkisinde kiriş ekseni boyunca sabit olan kesme kuvveti, düşey yük ve depremin ortak etkisinde -düşey yük etkisinin belirli mertebede olmasıyla- işaret değiştirebilir. Kesme kuvvetinin işaret değişimi, negatif eğilmeye zorlanan kiriş mesnet kesitinde maksimum eğilme momentinin kolon yüzünde oluşmasına, pozitif eğilmeye zorlanan kiriş mesnet bölgesinde ise maksimum eğilme momentinin mesnetten açıklık bölgesine doğru kaymasına neden olur. Düşey yük etkisinin deprem etkisine göre sınırlı kaldığ 1 durumlarda, kesme kuvvetinin kiriş ekseni boyunca işaret değiştirmemesine bağlı olarak, kirişte oluşacak eğilme momentinin en büyük değerleri daima kolon yüzünde oluşacaktır. Kiriş ekseni boyunca kesme kuvvetindeki değişime bağlı biçimde açıklanan bu farklı plastik mafsal mekanizması oluşumları ve hasar biçimleri Şekil 2'de şematik olarak gösterilmiştir.

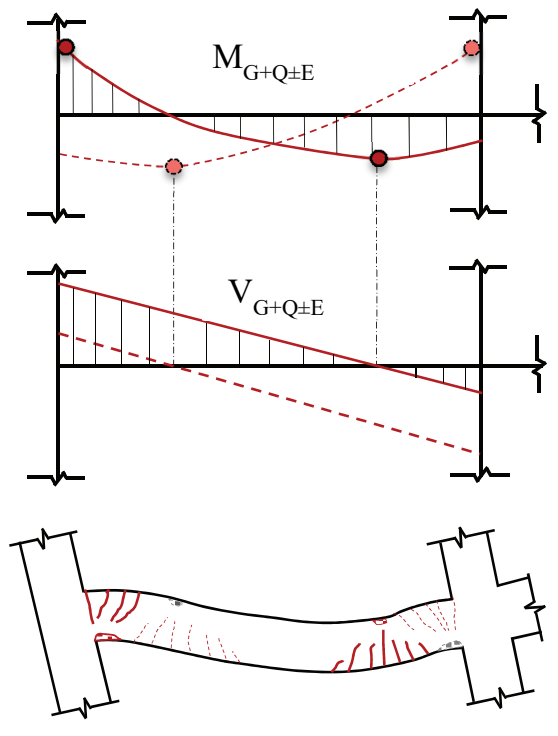

(a) Kritik Kiriş Kesitinde Tek Ĕgilme Doğrultusunda Plastik Mafsal Oluşumu
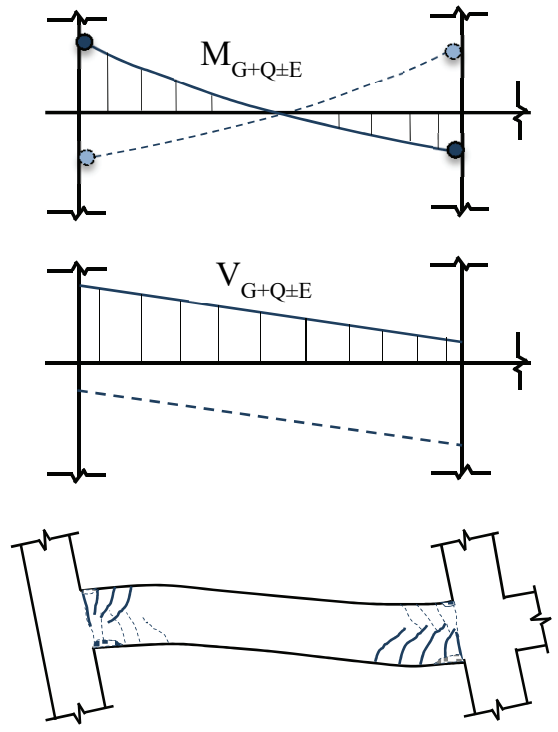

(b) Kritik Kiriş Kesitinde İki Ĕğilme Doğrultusunda Plastik Oluşumu

Şekil 2 - Çevrimsel yükle zorlanan betonarme çerçeve kirişlerinin kritik kesitlerinde, (a) tek ve (b) çift yönlü plastik mafsal mekanizması durumları ve hasar biçimleri

Depreme dayanıklı bina tasarım yönetmelikleri, binaların elastik ötesi davranış sergilemesine; yapıların başta gevrek güç tükenmelerine karşı yeterli dayanıma sahip olması, potansiyel hasar noktalarında kabul edilebilir hasar ile enerjiyi tüketebilecek plastik dönme yapabilme yeteneğine sahip olması gibi çeşitli tasarım kurallarının sağlanması şartıyla izin 
vermektedir. Yönetmeliklerde uygulanan kuvvetli kolon-zayıf kiriş prensibi, kolon kiriş birleşim bölgesi kesme güvenliği yaklaşımı ve kapasite tasarımı gibi tasarım kuralları [2, 3], yapıda aşırı zorlamalar altında ortaya çıkabilecek potansiyel hasarın eğilmeden kaynaklanmasına ve hasar bölgelerinin yaygın olarak kiriş mesnet kesitlerinde gerçekleşmesine neden olur. Bu nedenle, kiriş mesnet kesimlerinin plastik mafsal dönme kapasitesi, yapısal performansın değerlendirilmesi açısından önem taşır ve uzun süreden beri deneysel çalışmalarda inceleme konusu olmuştur [4 11]. Bu deneysel incelemelerde deprem etkisinin yerdeğiştirme kontrollü tersinir çevrimsel yüklere benzeştirilerek uygulandığı statik benzeri (Quasi-Statik) testler, -basitliği nedeniyle- yaygın olarak tercih edilmektedir. Numunelerin hem pozitif hem de negatif eğilme yönünde elastik ötesi davranış sergileyecek şekilde zorlandığ 1 bu deneylerde, numunelere çeşitli dokümanlarda [12 14] önerilen çevrimsel yer değiştirme geçmişleri uygulanarak, elastik ötesi zorlanan deney elemanının yük ve yer değiştirme kapasitesi belirlenebilmektedir. Statik benzeri test yönteminin uygulandığ deneysel incelemelerde, yaygın olarak deney numunelerinde hem pozitif hem de negatif eğilme doğrultularında elastik ötesi davranış meydana getiren yükleme geçmişlerinin kullanıldığı, bir başka ifadeyle düşey yük etkisinin belirgin mertebede olmadığının varsayıldığ 1 söylenebilir.

Belirgin düşey yükün davranış üzerindeki etkisine yönelik literatürde sınırlı sayıda çalışma vardır. Meggett ve Fenvick [15] tarafından yapılan deneysel çalışmada, tek açıklıklı betonarme bir çerçeve sistem, yatay çevrimsel yük ve kiriş açıklığına uygulanan düşey yük etkisi altında incelenmiştir. Deneysel incelemede düşey yükün kiriş plastik mafsal çalışma biçimini etkilediği, belirgin mertebedeki düşey yükün tek yönlü plastik mafsal oluşumuna neden olduğu ve düşey yük etkisinin belirginleşmesiyle tek yönlü oluşan kiriş plastik mafsalındaki dönme kapasitesinin büyüdüğü gösterilmiştir. Walker ve Dhakal [16] tarafından yapılan deneysel incelemede, plastik mafsal davranış farklılığının yer değiştirme kapasitesi üzerinde belirgin etkisi olduğu ve tek yönlü plastik mafsal davranışı sergileyen kirişlerin göçme sınır eğrilik sünekliği oranlarının, çift yönlü plastik davranış sergileyen kirişlerin eğrilik sünekliği oranlarının iki katı olarak alınabileceği önerilmiştir. Gião vd. [17] tarafından yapılan deneysel incelemede, belirgin düşey yük etkisine maruz kirişlerde statik benzeri testler için esas alınabilecek bir deney prosedürü geliştirilmiş ve fiziksel deney sonuçları ile analitik sonuçlar karşılaştırılmıştır. Ülkemizde de belirgin düşey yük etkisi ile birlikte depremi benzeştiren yüklemenin birlikte dikkate alındığı çalışmalar yapılmıştır. Kaya vd. [18] tarafindan yapılan deneysel incelemede, düşey işletme yükünden kaynaklanan negatif eğilme momenti, çevrimsel ve artan genlikli yer değiştirme kontrollü yükleme öncesi numunelere uygulanarak, belirgin mertebedeki düşey işletme yükünün plastik mafsal davranış biçimi üzerindeki etkisi dikkate alınmıştır.

Türk Deprem Yönetmeliği’nde [2] yer alan bazı hesap esasları plastik mafsal davranış biçimine bağlı biçimde değişkenlik gösterebilmektedir. Betonun kesme dayanımına katkısının belirlenmesi bu duruma örnek olarak gösterilebilir. Yönetmelik'e göre; sadece deprem yüklerinden oluşan kesme kuvveti, depremli durumdaki toplam kesme kuvveti ile karşılaştırılarak, tek yönlü plastik mafsal davranışı durumunda betonun kesme dayanımına katkısı dikkate alınırken; çift yönlü plastik mafsal durumunda ise betonun kesme dayanımına katkısı ihmal edilmektedir. Yönetmelikteki mevcut yapıların değerlendirilmesi ve güçlendirilmesi bölümünde ise, farklı hasar düzeylerine karşı gelen yer değiştirme sınırları, plastik mafsal davranış biçiminden bağımsız olarak ifade edilmektedir. Bu çalışmada, eğilme kırılmasıyla taşıma gücüne ulaşan betonarme kirişlerde plastik mafsal davranış biçimi 
farklılığının Göçme Hasar Sınırı Yer değiştirmesi üzerine etkileri incelenmiştir. Deney programında, yönetmelikte verilen yanal donatı miktar ve aralık sınırlarına uygun olan ve bu koşulların bazılarını sağlayamayan iki farklı deney numunesi kullanılmıştır. Deneysel incelemelerde, numunelerin tek ve çift yönlü plastik mafsal davranışı durumlarındaki hasar sınır yer değiştirmeleri, plastik mafsal boyları, toplam kesit eğrilikleri, malzeme birim şekil değiştirme değerleri ve çeşitli yönetmeliklerde verilen hasar sınırı yaklaşımı [2, 3, 19 ve 20] sonuçlarıyla karşıllaştırılmıştır.

\section{DENEY PROGRAMI}

\subsection{Deney Numunelerinin Detayları ve Test Düzeni}

İstanbul Aydın Üniversitesi İnşaat Mühendisliği Laboratuvarında üretilerek test edilen deney numunelerinin geometrisi ve donatı detayları Şekil 3'de, deney programında uygulanan test düzeni ise Şekil 4'de gösterilmiştir. Çevrimsel ve tekrarlanan tür zorlamalarda kiriş plastik mafsal bölgelerinde tabla betonunun çekme etkisiyle çatlamış olacağı kabulüyle deney
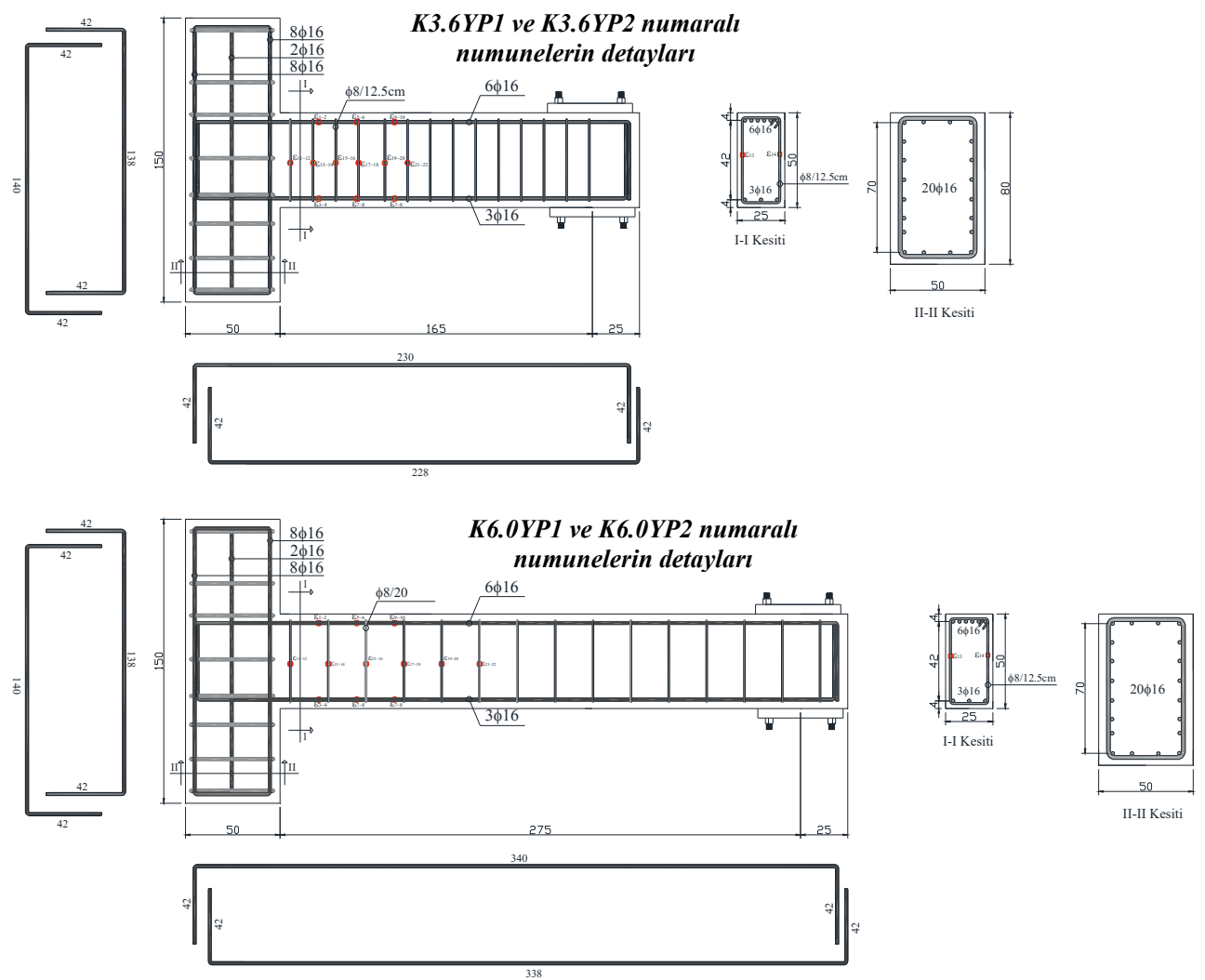

Şekil 3 - Numune detayları ve birim şekil değiştirme ölçerlerin konumları 
numuneleri çift donatılı dikdörtgen kesit olarak tasarlanmıştır [21]. Ayrıca tabla betonunun çekmeye zorlanması durumunda, döşeme donatılarının eğilme kapasitesini arttırıcı etkisi [22] göz önüne alınmamıştır. Konsol olarak üretilen deney numunelerinde yük uygulama noktası gerçek yapıda moment sıfır noktasını, konsol kirişin mesnedi ise gerçek yapıda rijit bir kolonu simgelemektedir. Deney numuneleri, kiriş kesme açıklığı / kesit etkili derinliği oranları (a/d) ve yükleme geçmişleri (YP) kullanılarak isimlendirilmiştir. Kesme açıklığının kesit etkili derinliğine oranı 3.6 ve 6.0 olacak şekilde imal edilen toplam 4 adet deney numunesinin genel özellikleri ise Çizelge 1 'de özetlenmiştir.

Bilindiği üzere Türk Deprem Yönetmeliği’nde [2] göçme hasar sınır durumu için tanımlanan sargılı beton sınır birim şekil değiştirmesi, kirişin yanal donatısının yönetmelikte ön görülen yanal donatı gereksinimine oranlanarak ifade edilmektedir. Deney programında, enine donatı gereksinimi kapasite tasarımı ilkesine göre belirlenen 4 numuneden, a/d oranı 6.0 olan iki numunede -kesme kuvveti talebi diğer numunelere göre düşük mertebede olduğundanseçilen enine donatı aralığı, yönetmelikte öngörülen sınırların üzerinde tutulmuştur (Bkz. Çizelge 1). Böylece yanal donatı sınırlamasına uygun olmayan kirişler için, yönetmelikte tanımlanan sargılı birim şekil değiştirme sınırının göçme hasar sınırını ne ölçüde betimlediği, deneysel sonuçlar ile karşıllaştırılarak, irdelenebilecektir.

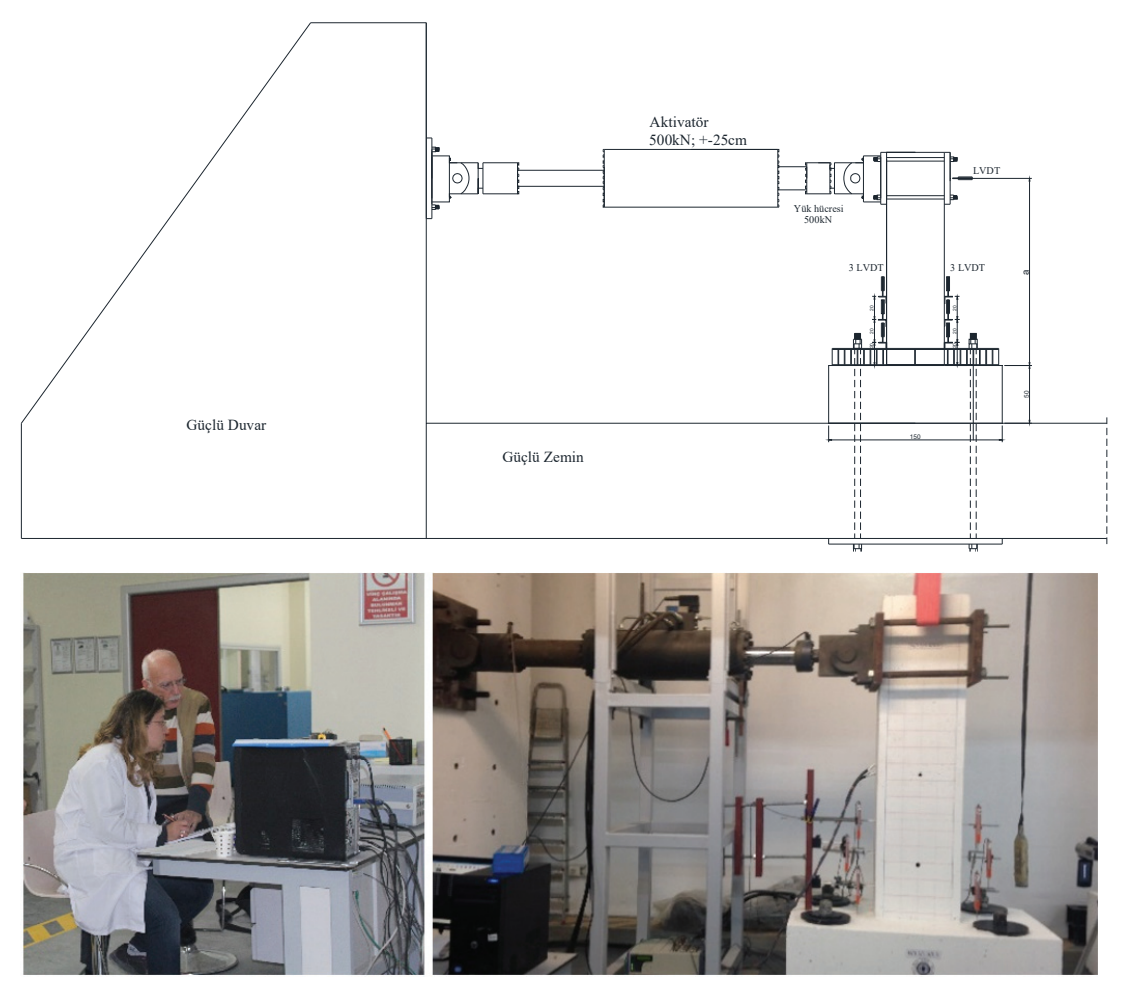

Şekil 4 - Test düzeni 
Çizelge 1 - Deney numunelerinin özellikleri

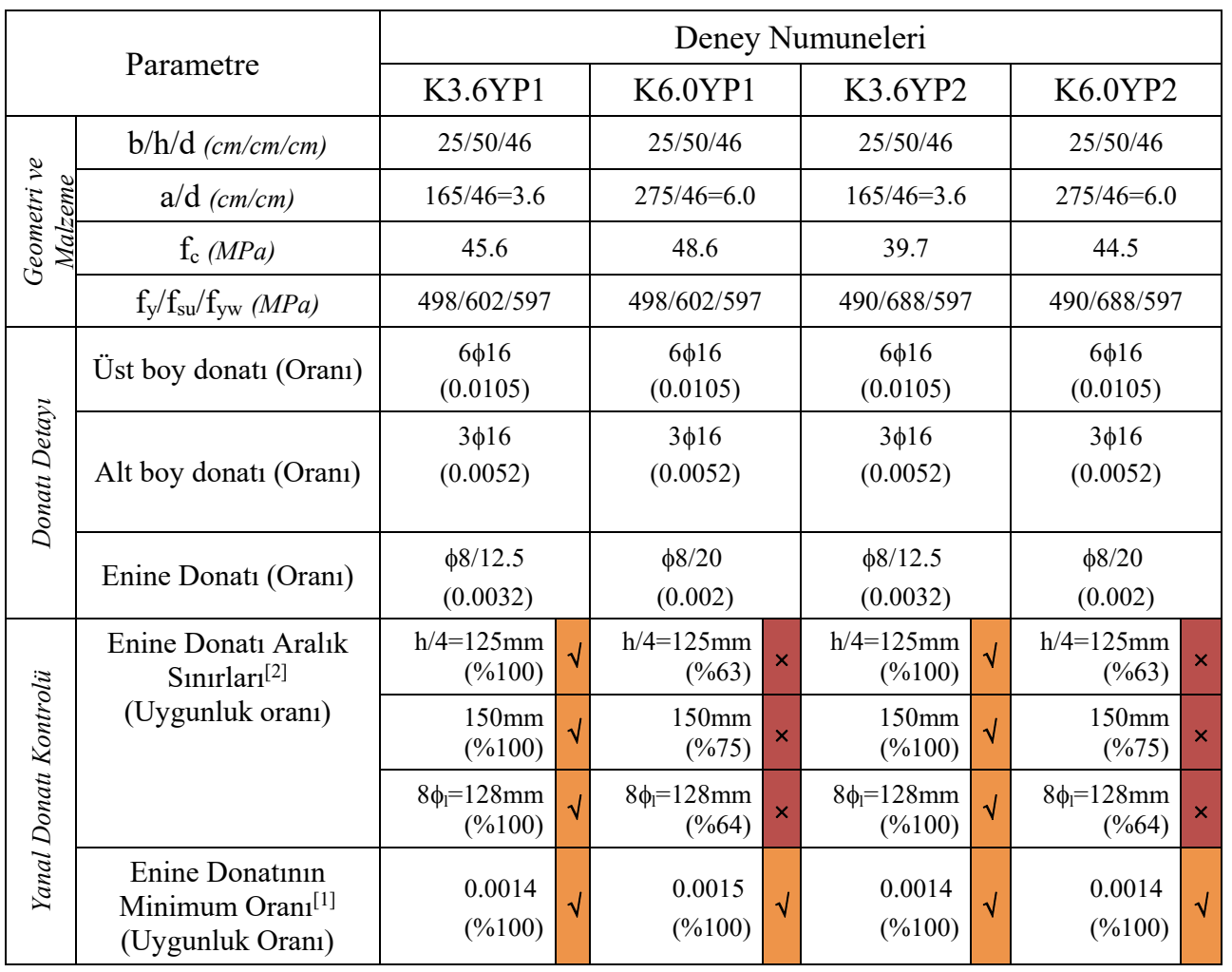

\subsection{Yükleme Geçmişleri}

Deney programında iki ayrı yükleme geçmişi uygulanmıştır. Düşey yük etkisini içermeyen ya da düşey yükün belirgin mertebede olmaması durumu için uygulanan yükleme, YP1 olarak isimlendirilmiştir. YP1 yükleme geçmişi, potansiyel hasar bölgesinde çift yönlü plastik davranış hedeflenerek hazırlanmıştır. Düşey yükün belirgin mertebede olduğu varsayımıyla uygulanan YP2 yükleme geçmişinde ise potansiyel hasar bölgesinde tek yönlü plastik davranış hedeflenmiştir. YP1 yükleme geçmişi sadece yerdeğiştirmenin kontrol edilmesiyle uygulanırken, YP2 yükleme geçmişi hem kuvvet hem de yerdeğiştirmenin birlikte kontrol edilmesiyle uygulanmaktadır. YP1 ve YP2 yükleme geçmişleri arasındaki farklılıkların daha belirgin bir biçimde karşılaştırılabilmesi için her iki yükleme geçmişinin 3 tekrarlı tipik bir çevrimi Şekil 5'de yan yana gösterilmiştir.

Şekil 5.a'da tipik bir çevrimi görülen YP1 isimli yerdeğiştirme kontrollü yükleme, numunelerin analitik akma yerdeğiştirmeleri yardımıyla belirlenen nominal yerdeğiştirme sünekliği oranları hedeflenerek hazırlanmıştır. YP1 yükleme geçmişinde hedef alınan nominal yerdeğiştirme sünekliği oranları Şekil 6'dan görülebilir. 

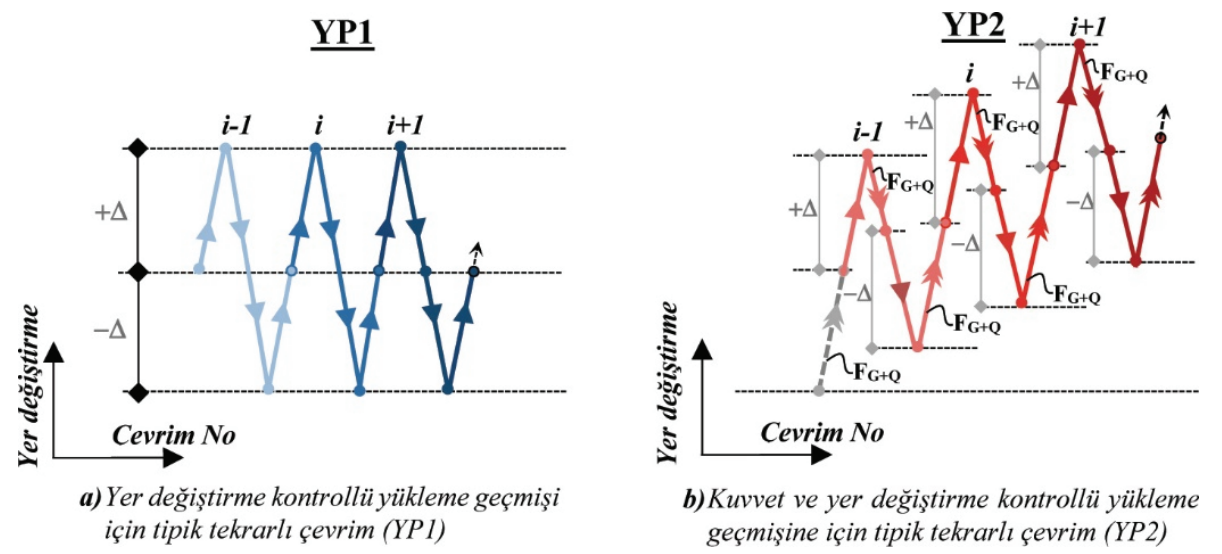

Şekil 5 - Yükleme geçmişlerinin tipik bir çevrimleri (a) YP1, Yer değiştirme kontrollü yükleme (b) YP2, Kuvvet ve yerdeğiştirme kontrolünün birlikte uygulandı̆̆ yükleme

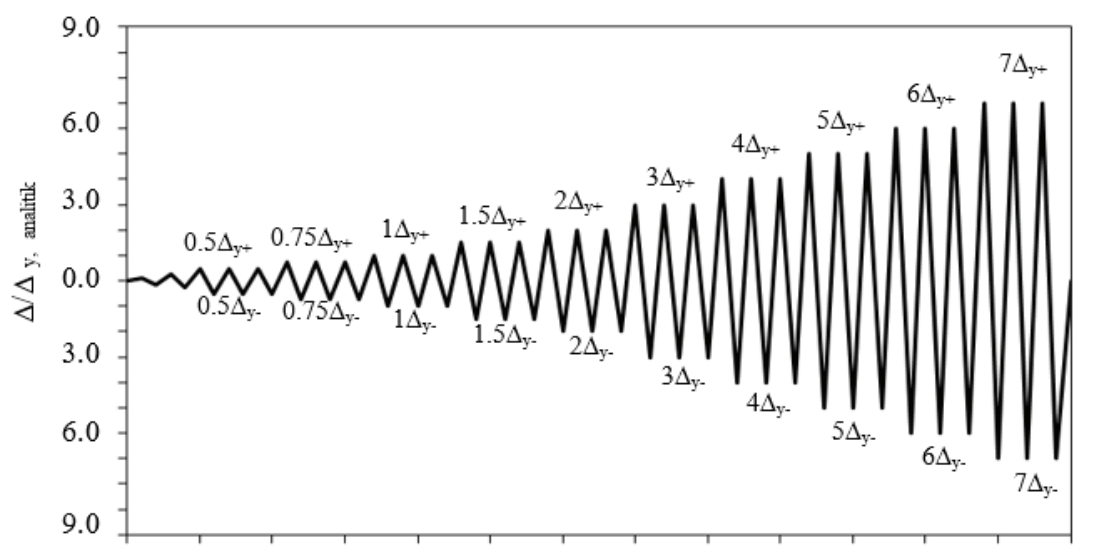

Şekil 6 - YP1 numarall yükleme geçmişinin yerdeğiştirme sünekliği ile gösterimi

Düşey yüklerin tek yönlü eğilme etkisinin kuvvet kontrolüyle, depremin tersinir etkisinin yerdeğiştirme kontrolüyle uygulandığ1 YP2'nin tipik tekrarlı çevrimi Şekil 5.b'de şematik olarak gösterilmiştir. YP2 yüklemesinde ilk adım -kuvvet kontrolünde- düşey işletme yükünün $\left(\mathrm{F}_{\mathrm{G}+\mathrm{Q}}\right)$ uygulanmasıdır. Şekil 5.b'de tipik tekrarlı çevrimde düşey işletme yükünün yüklenip boşaltıldığı tekrarlı yükleme çevrimleri, elastik ötesi aşamada numune rijitliğinin bir önceki adıma göre azalacağı ve dolayısıyla numunenin yer değiştirme cevabının artacağı varsayılarak, şematik olarak çizilmiştir. YP2 yüklemesinde düşey işletme yükün uygulama değeri $\left(\mathrm{F}_{\mathrm{G}+\mathrm{Q}}\right)$, kesiti akma limit duruma getiren yükün yarısı $\left(\mathrm{F}_{\mathrm{y}} / 2\right)$ olarak dikkate alınmıştır [17]. YP2 yükleme geçmişinin tipik bir çevrim uygulamasında izlenen adımlar şu şekilde özetlenebilir. İşletme yükü etkisindeki numuneye yer değiştirme kontrolünde nominal yerdeğiştirme sünekliği oranına bağlı olarak belirlenen pozitif bir ilave yer değiştirme uygulanır. Yerdeğiştirme kontrollü adımın tamamlanmasının ardından, düşey işletme yükü kuvvet kontrolünde boşaltılır. Kuvvet kontrollü adım sonrası nominal yerdeğiştirme 
sünekliği oranına bağlı olarak belirlenen negatif doğrultudaki yer değiştirme, yerdeğiştirme kontrollü olarak uygulanır. Yerdeğiştirme kontrollü yükleme sonrası, işletme yükü numuneye kuvvet kontrolünde uygulanarak yükleme geçmişinin bir çevrimi tamamlanmaktadir [17].
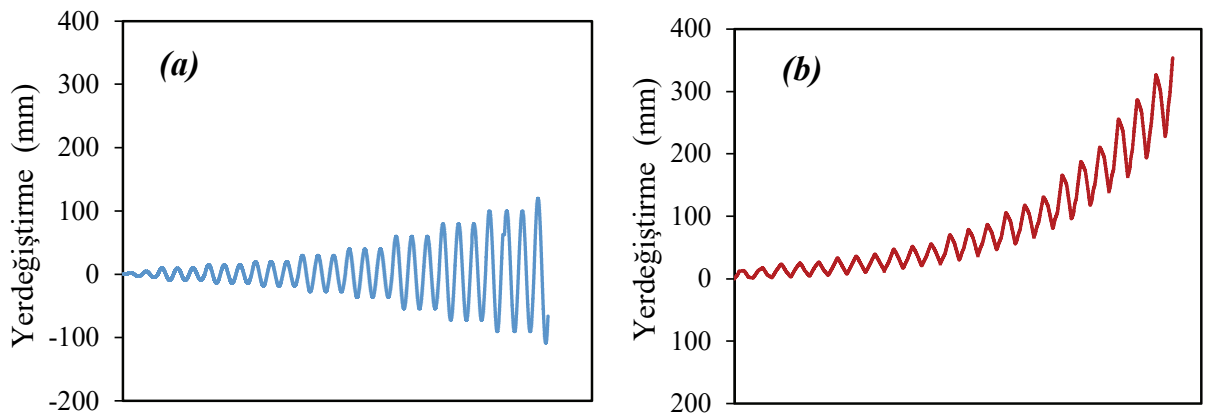

Şekil 7 - Yükleme geçmişleri (a) K6.0YP1 numunesine yer değiştirme kontrollü uygulanan yükleme geçmişi (b) K6.0YP2 numunesine kuvvet ve yerdeğiştirmenin birlikte kontrolüyle uygulanan yükleme geçmişi

Çizelge 2 - Yükleme geçmişi kontrolünde uygulanan hedef yerdeğiştirme ve kuvvet değerleri

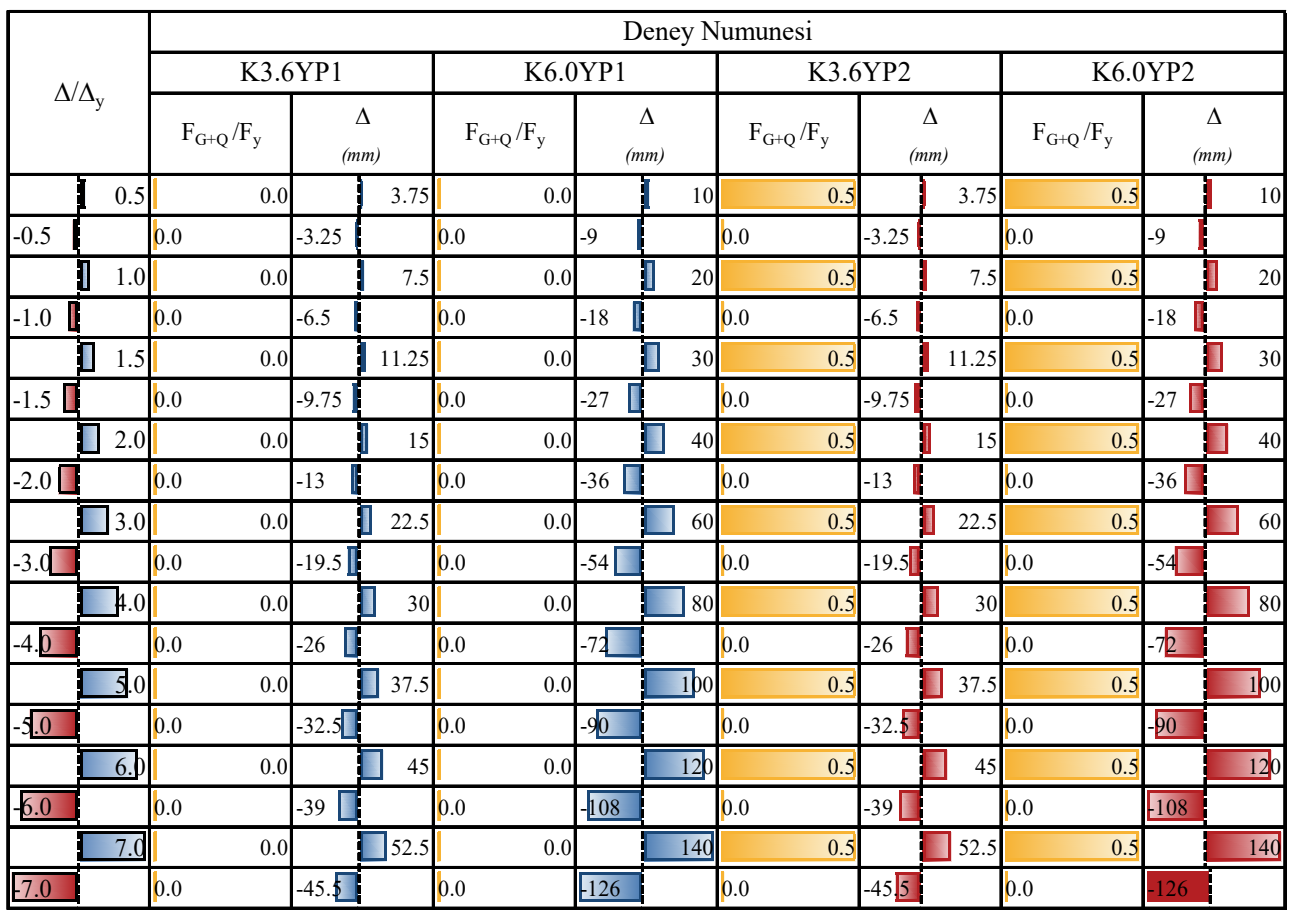


YP1 ve YP2 yükleme geçmişlerinin hazırlanmasında hedef alınan nominal yerdeğiştirme sünekliği oranları, akma yer değiştirmeleri ve düşey işletme yükünün hedef değerleri Çizelge 2 'de özetlenmiştir. Çizelgeden de görüleceği üzere, kesme açıklığının kesit etkili derinliğine oranı 3.6 ve 6.0 olan numunelerde yerdeğiştirme hedef değerleri birbirinden farklıdır. K3.6YP1 ve K6.0YP1 numunelerinde yerdeğiştirme hedeflerinin birbirinden farklı olması ve ayrıca itme ve çekme doğrultularında değişkenlik göstermesi, numune boylarının farklı olması ve numunelerde itme ile çekme doğrultularında akma yer değiştirmelerinin farklılık $\left(+\Delta_{\mathrm{y}} \neq-\Delta_{\mathrm{y}}\right)$ göstermesinden kaynaklanmaktadır.

Yerdeğiştirme sünekliği oranları bakımından birbirine özdeş olan ve K6.0YP1 ve K6.0YP2 numunelerine uygulanan YP1 ve YP2 yükleme geçmişleri, Şekil 7'de gösterilmiştir.

\section{DENEYSEL SONUÇLAR VE DEĞERLENDİRİLMESİ}

Çalışmanın bu bölümünde, düşey işletme yükünün ihmal edildiği ve belirgin mertebede olduğu kabulleriyle hazırlanan iki farklı tersinir-çevrimsel yüklemeyle göçme durumuna kadar zorlanan numunelerin deneysel sonuçları, karşılaştırmalı olarak irdelenecektir. Deney numunelerinin yük-yer değiştirme ve moment-dönme ilişkileri Şekil 8 11'de diyagramlar halinde verilmiştir. Deney sırasında meydana gelen ve gelişen hasarı betimlemek amacıyla gözlenen ve/veya ölçülen çeşitli sınır durumlar, bu diyagramlar üzerine işaretlenmiştir. Numunelerin deney sonu göçme biçimleri ise Şekil 12'de verilen fotoğraflar ile topluca gösterilmiştir. Deney numunelerinin tamamı taşıma gücü sınır durumuna eğilme kırılmasıyla ulaşmış olup, deney sırasında numunelerde gözlenen hasar durumları aşağıda kısaca özetlenmiştir.

Şekil 8 ve Şekil 10'da verilen yük-yerdeğiştirme ilişkilerinden de görüleceği üzere, K3.6YP1 ve K6.0YP1 numunelerinde, hem pozitif hem de negatif eğilme doğrultusunda yön değiştiren (çift yönlü) plastik mafsal oluşumu söz konusudur. İki deney numunesinde de güç tükenmesi hasar durumları eğilme yönüne göre değişkenlik göstermiştir. Kiriş kesiti üst donatılarını çekmeye çalıştıran eğilme zorlamasında, güç tükenmesi basınç donatılarının burkulmasıyla, tersi yönünde eğilme etkisinde güç tükenmesi ise çekme donatılarında kopma ile meydana gelmiştir. Sözü edilen her iki hasar durumu da, deney numunelerinin boyuna donatı oranının düşük olduğu tarafta meydana gelmiştir. Deney numunelerinin kuvvet-yer değiştirme davranışının simetrik olmaması ve kesitin alt yüzündeki boyuna donatıda gözlenen hasar durumları, kiriş boyuna donatı düzeninin simetrik olmamasından kaynaklanmaktadır. Benzer şekilde, yön değiştiren ya da çift yönlü plastik mafsal oluşumu gözlenen numunelerin rijitliğinde eğilme yönüne göre davranış farklılığı, simetrik olmayan donatı düzeni ve tersinir yüklemede her iki eğilme doğrultusunda da çekme hasarına bağlı gelişen çatlak oluşumundan kaynaklanmaktadır.

Şekil 9 ve Şekil 11'den de görüleceği üzere K3.6YP2 ve K6.0YP2 numunelerinde yön değiştirmeyen, bir başka ifadeyle tek yönlü plastik mafsal oluşumu söz konusudur. Bu durum, işletme yükü ve deprem ortak etkisinde kiriş mesnet kesitinin elastik ötesi zorlanması; işletme yükü ve ters yönlü zorlanma yaratan deprem etkisinde ise kesitin plastik moment kapasitesinin altında zorlanması durumuna karşı geldiği yükleme durumlarına benzeştirilebilir. Deney numunelerinde göçme davranışı, boyuna donatı oranı düşük olan kesit alt yüz bölgesindeki donatıların burkulmasıyla ortaya çıkmaktadır. 


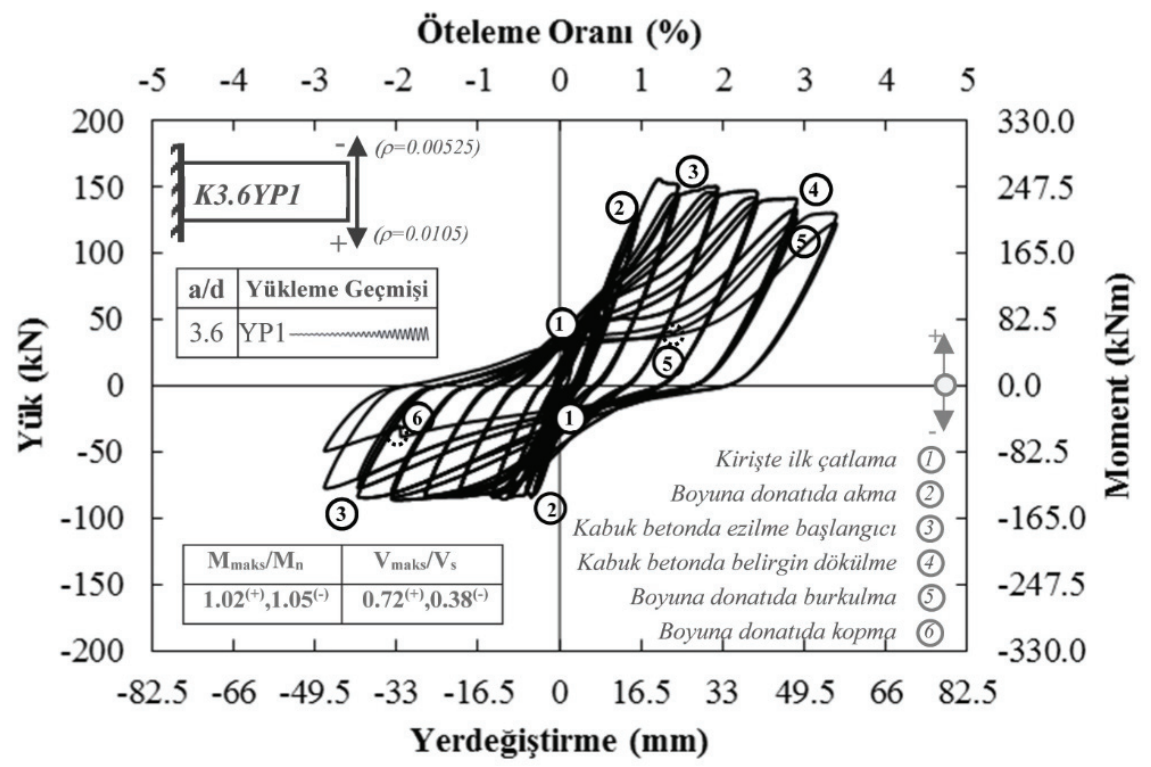

Şekil 8 - K3.6YP1 numunesinde çevrimsel yük-yerdeğiştirme ilişkisi

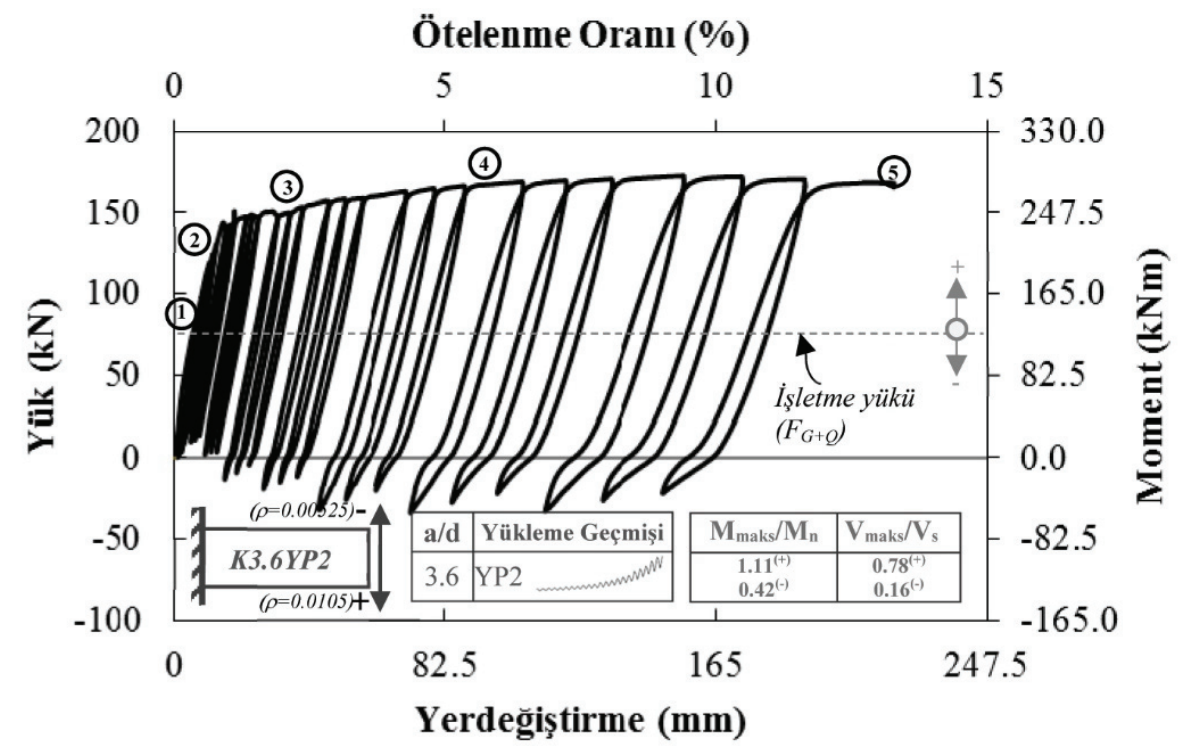

Şekil 9 - K3.6YP2 numunesinde çevrimsel yük-yerdeğiştirme ilişkisi 
Belirgin Düşey Yük Etkisindeki Betonarme Kirişlerin Çevrimsel Yükler Altındaki ...

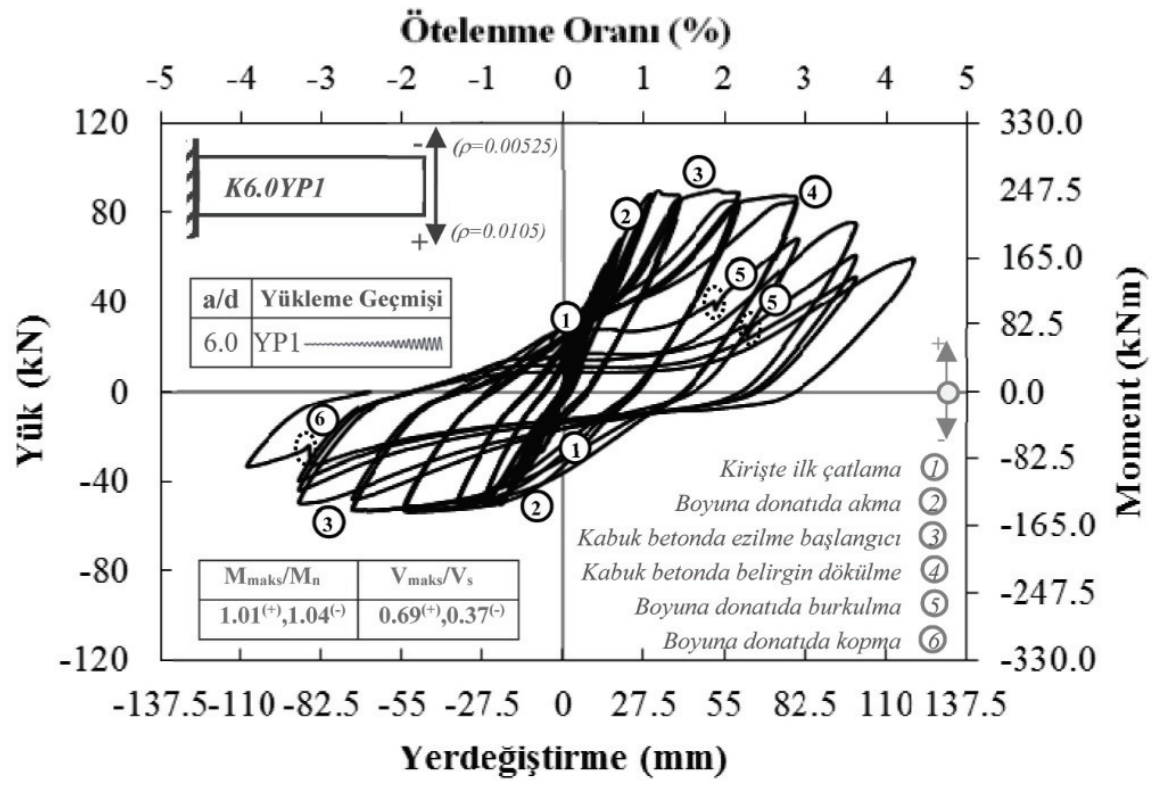

Şekil 10 - K6.0YP1 numunesinde çevrimsel yük-yerdeğiştirme ilişkisi

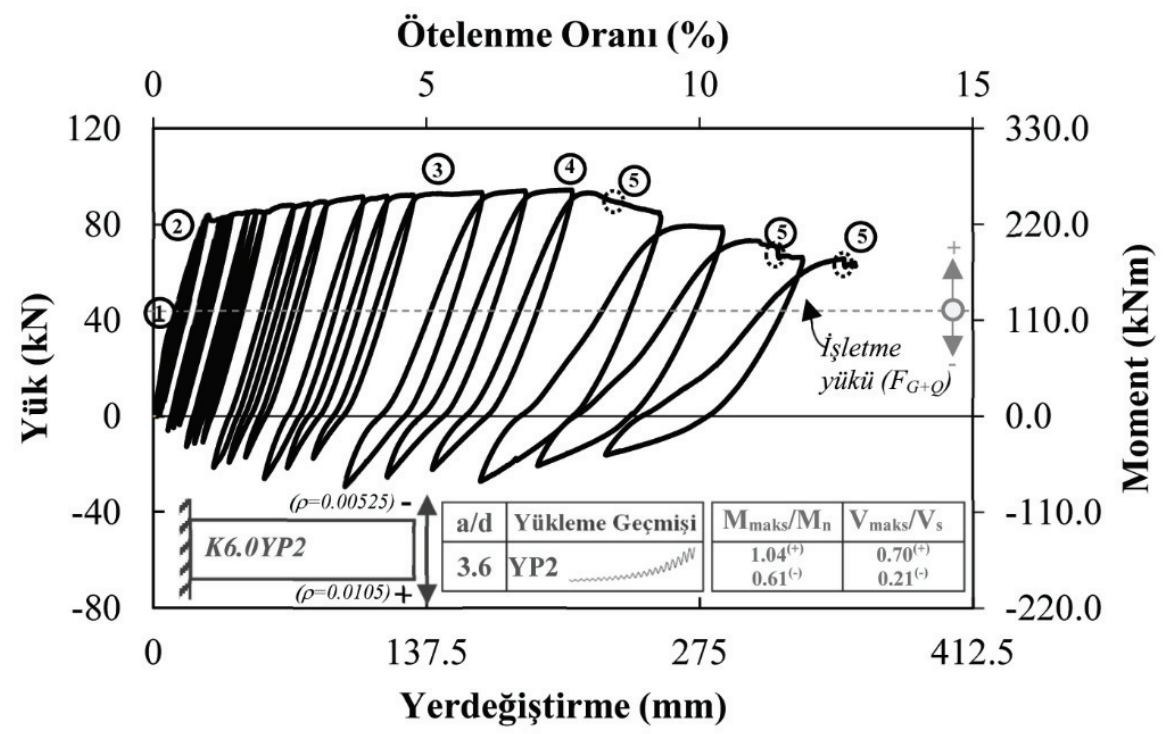

Şekil 11 - K6.0YP2 numunesinde çevrimsel yük-yerdeğiştirme ilişkisi 
K3.6YP2 numaralı numunede burkulmanın, sadece köşe donatıda meydana gelmesi nedeniyle yüklemeye bu noktada son verilmiş̧ir. K6.0YP2 numunesinde ise burkulma sonrası çevrimsel yükleme adımlarına bir miktar daha devam edilmiştir ve boyuna donatıda burkulma gözlenen her iki numune de düşey yük etkisini $\left(\mathrm{F}_{\mathrm{G}+\mathrm{Q}}\right)$ karşılama açısından yeterli kapasiteye sahip olmasına karşın, numunelere uygulanan yer değiştirme yeterli görülerek, deney sonlandırılmıştır.
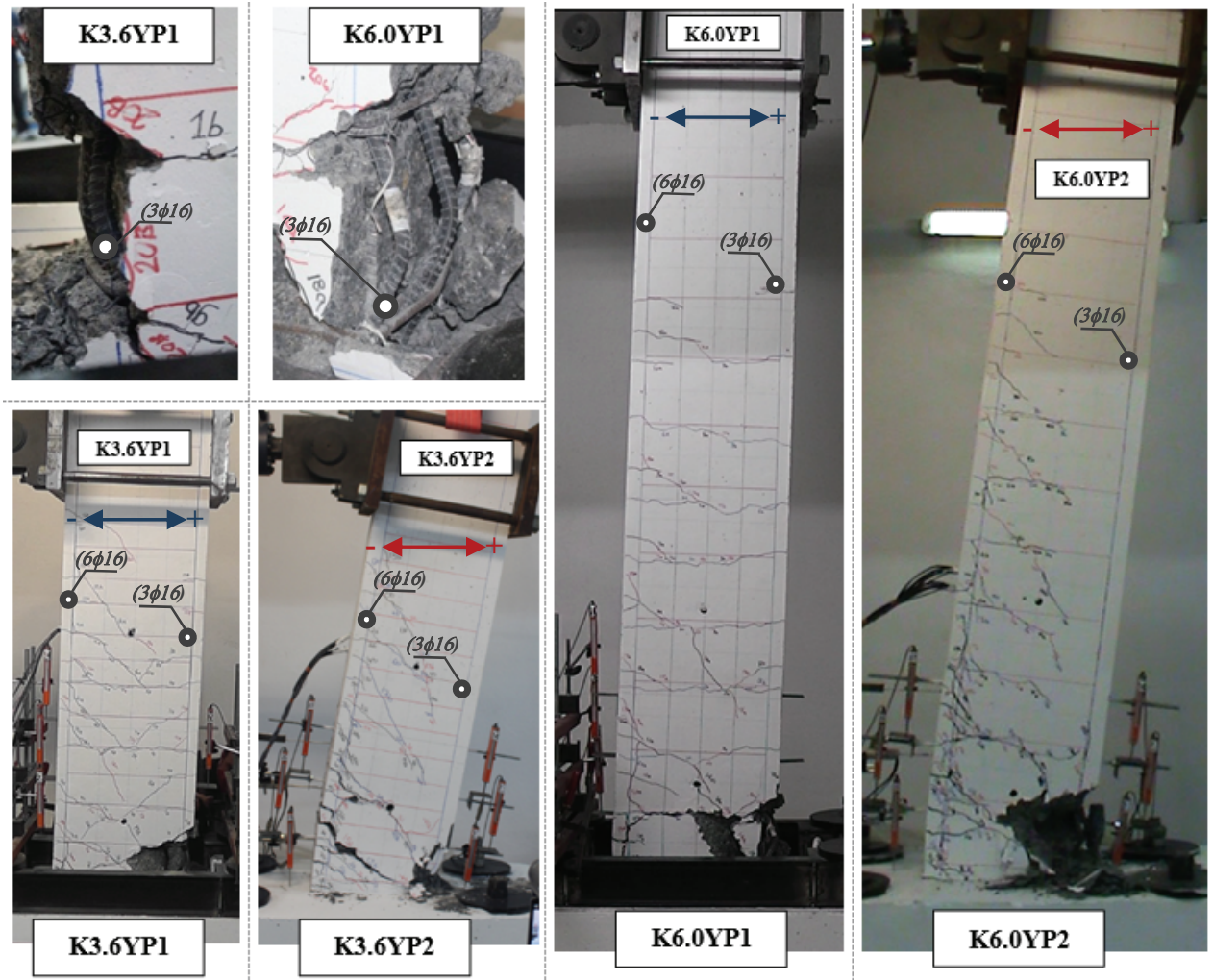

Şekil 12 - Deney numunelerinin göşme şekilleri

Şekil 8 11'den de görüleceği üzere, tek yönlü (yön değiştirmeyen) plastik mafsal oluşumu gözlenen deney numunelerinin plastik dönme kapasiteleri, çift yönlü (yön değiştiren) plastik mafsal oluşumu gözlenen deney numunelerinin plastik dönme kapasitelerinin oldukça üzerindedir. Bu belirgin farklılığa etki eden bileșenlerin değerlendirilmesinde, plastik dönme, plastik mafsal teorisinden [23] yararlanılarak bileşenlerine ayrılacaktır. Bilindiği gibi elastik ötesi zorlanan betonarme bir kesitte plastik dönme $\left(\theta_{\mathrm{p}}\right)$, kesitin plastik eğriliği $\left(\phi_{\mathrm{p}}\right)$ ve plastik mafsal boyuna $\left(L_{p}\right)$ bağlı biçimde (1) bağıntısıyla ifade edilebilir.

$\theta_{p}=\phi_{p} \cdot L_{p}=\left(\phi_{u}-\phi_{y}\right) \cdot L_{p}$ 
(1) bağıntısında $\phi_{\mathrm{u}}$ kesitin toplam eğriliğini ve $\phi_{\mathrm{y}}$ ise kesitin akma eğriliğini göstermektedir. Betonarme bir kesitin birim boydaki dönme açısına karşı gelen toplam kesit eğriliği, kesitin en dış basınç ve çekme yüzü malzeme birim şekil değiştirmeleri $\left(\varepsilon_{\mathrm{cm}}, \varepsilon_{\mathrm{sm}}\right)$ ve tarafsız eksen derinliğine (x) göre (2) bağıntısıyla ifade edilebilir.

$$
\phi_{u}=\frac{\varepsilon_{c m}}{x}=\frac{\varepsilon_{s m}}{d-x}
$$

Çift ya da tek yönlü plastik mafsal davranışı sergileyen deney numunelerinde, plastik mafsal boylarının dönme talebine göre değişimleri Şekil 13'deki diyagramlar üzerinde karşılaştırılarak, gösterilmiştir. Deney numunelerinin elastik ötesi davranış sergilediği bölgede, plastik mafsal boylarının saptanmasında akma limit durum, boyuna donatılara yerleştirilen birim şekil değiştirme ölçerler yardımıyla, toplam eğrilik ise mesnet bölgesinde 3 ayrı ölçüm noktasında yer alan LVDT yer değiştirmeleri yardımıyla belirlenmiştir.
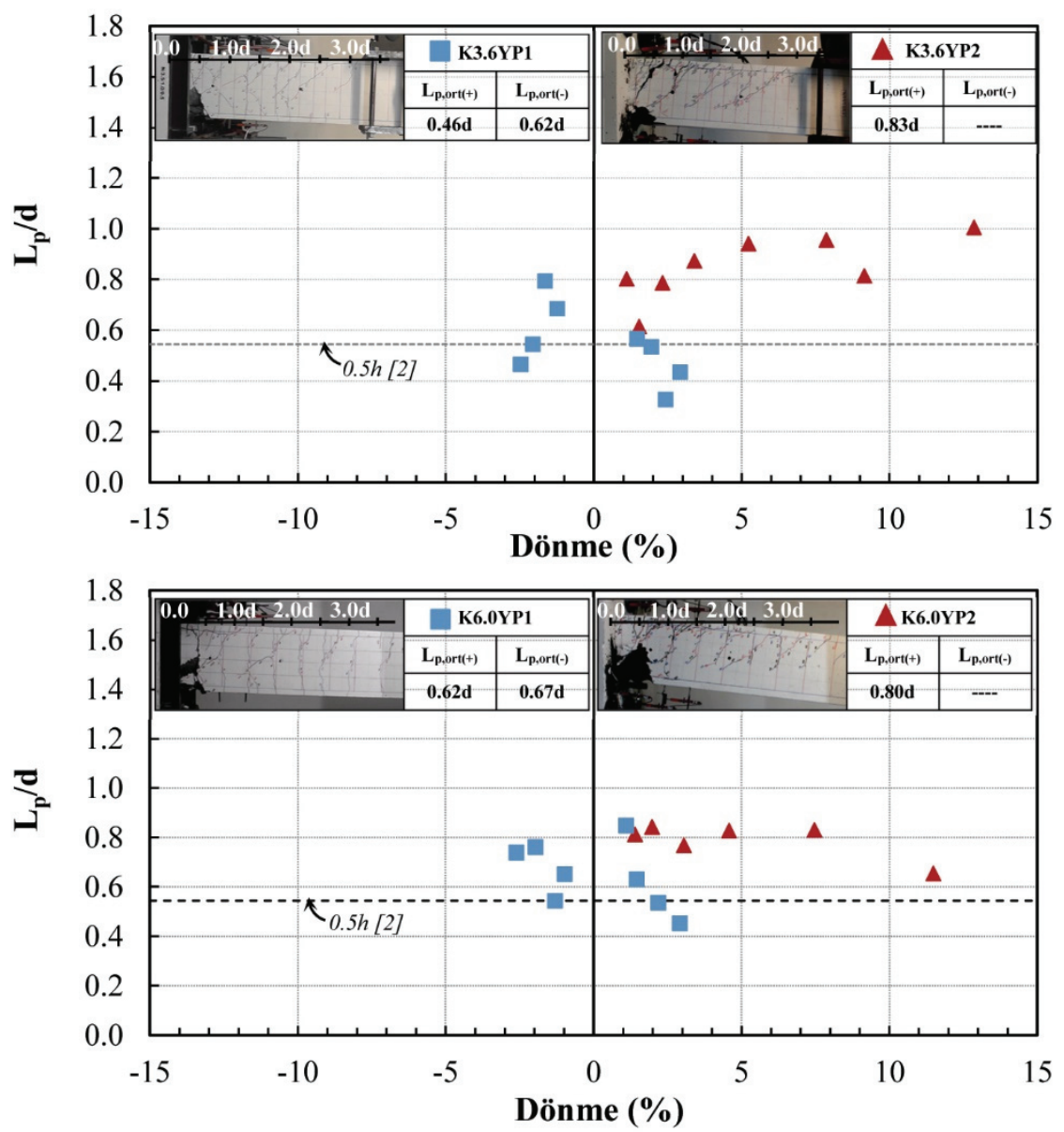

Şekil 13 - Deney numunelerinde plastik mafsal boyunun dönme talebine göre değişimleri 
Şekil 13'den de görüleceği üzere, yön değiştiren plastik mafsal davranışı gözlemlenen K3.6YP1 ve K6.0YP1 numunelerinin plastik mafsal boyları, eğilme yönü ve a/d oranına göre farklılık göstermiştir. Numunelerde, donatı oranı yüksek olan yüzdeki boyuna donatıları çekmeye zorlayan eğilme etkisinde $\mathrm{L}_{\mathrm{p}} / \mathrm{d}$ oranları, sırasıyla 0.46 ve 0.62 , diğer eğilme doğrultusunda ise bu oranlar 0.62 ve 0.67 olarak gerçekleşmiştir. Bu değerler, Türk deprem yönetmeliğindeki $\mathrm{L}_{\mathrm{p}} \approx 0.5 \mathrm{~h}$ [2] kabulüyle karşılaştırıldığında, deneysel ve analitik plastik mafsal boyları arasındaki oranların $\pm \% 15$ arasında değiştiği ve yönetmelik kabulünün, boyuna donatı azaldıkça ya da a/d oranı arttıkça genelde ihtiyatlı sonuçlar verdiği söylenebilir. Tek yönlü (yön değiştirmeyen) plastik mafsal davranışı sergileyen K3.6YP2 ve K6.0YP2 numunelerinin plastik mafsal boyları, yön değiştiren plastik mafsal davranış1 gözlenen numunelerin plastik mafsal boylarının üzerindedir. Yönetmelikte [2] verilen yanal donatı minimum şartlarını sağlayan K3.6YP2 numunesi plastik mafsal boyu, özdeş K3.6YP1 numunesinin plastik mafsal boyuna oranlandığında, ortalama plastik mafsal boyları arasındaki oran 1.8, son limit durumdaki plastik mafsal boyları arasındaki oran ise 2.3'tür. K6.0YP2 numunesinin K6.0YP1 numunesi plastik mafsal boyuna göre sözü edilen oranlar, sirasiyla 1.3 ve $1.7^{\prime}$ 'dir.

Şekil 14 ve Şekil 15'de tek ve çift yönlü plastik mafsal davranışı sergileyen numunelerin deneysel moment-eğrilik zarf ilişkileri, aynı diyagram üzerinde gösterilmiştir.

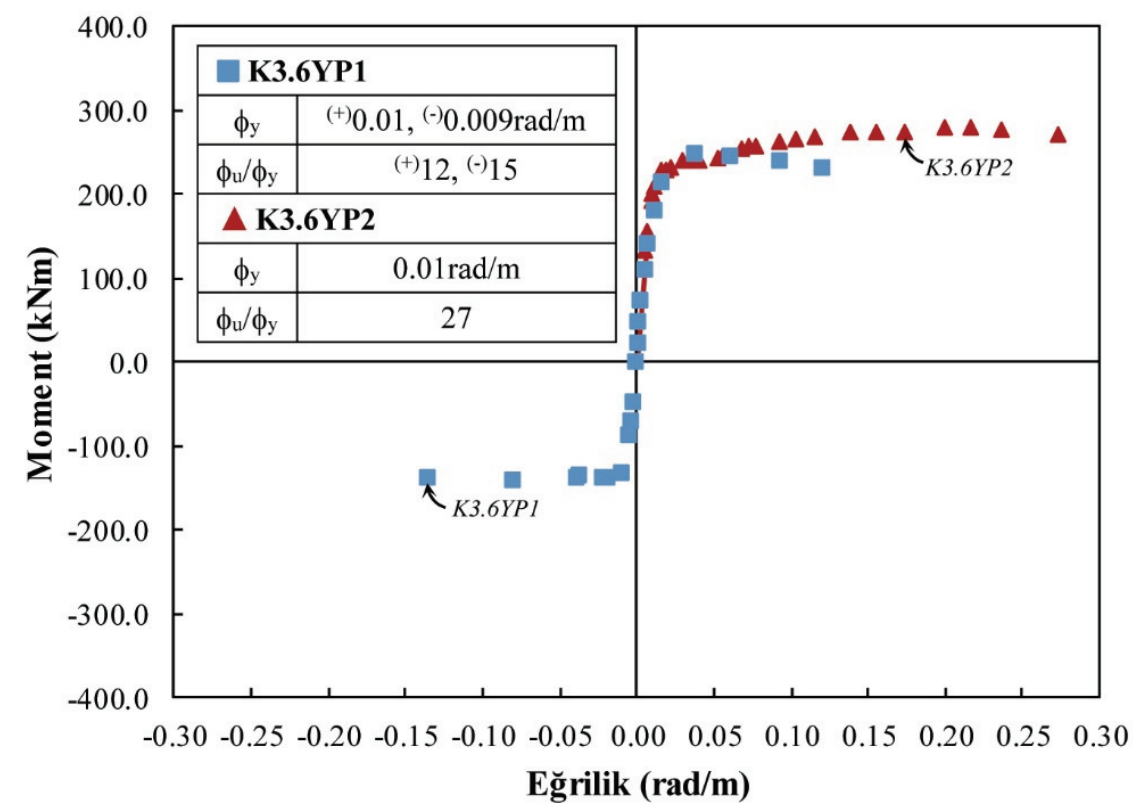

Şekil 14 - K3.6YP1 ve K3.6YP2 numunelerinde deneysel moment-eğrilik ilişkileri

Şekillerden de görüleceği üzere, deney numunelerinin akma limit durumuna karşı gelen kesit eğrilikleri birbirine oldukça yakın olmasına karşın, son limit eğriliklerinde belirgin farklılık söz konusudur. Bu farklılıkların daha kolay bir biçimde gözlenebilmesi amacıyla, 
numunelerin akma eğrilikleri ve eğrilik süneklik oranları $\left(\phi_{\mathrm{u}} / \phi_{\mathrm{y}}\right)$ moment-eğrilik diyagramları üzerinde çizelge halinde verilmiştir. Moment-eğrilik ilişskileri ve son limit durum eğrilik sünekliği oranlarının karşılaştırılmasından, tek yönlü plastik mafsal davranışı sergileyen numunelerin eğrilik sünekliği oranlarının, yön değiştiren plastik mafsal davranış1 sergileyen numunelere göre yaklaşık 2 kat daha büyük olduğu söylenebilir.

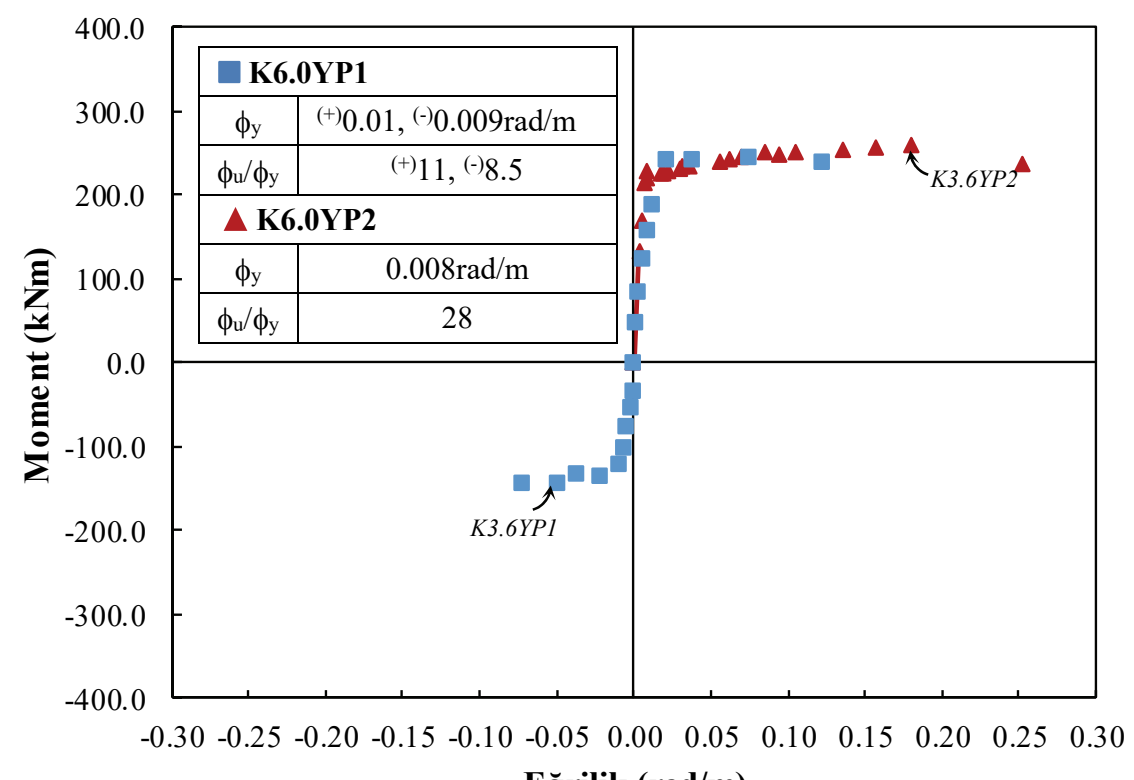

Ĕgrilik (rad/m)

Şekil 15 - K6.0YP1 ve K6.0YP2 numunelerinde deneysel moment-eğrilik ilişkileri

(2) bağıntısından görüleceği gibi, basınç ve/veya çekme bölgesi için tanımlanan malzeme birim şekil değiştirme sınırları, kesitin sınır eğriliğini ve dolayısıyla sınır dönme kapasitesini betimleyen önemli değişkenlerdir. Bu sınır birim şekil değiştirmelerdeki değişim, kesitin yük taşıma kapasitesi üzerinde sınırlı miktarda, plastik dönme kapasitesi üzerinde ise önemli miktarda değişime neden olur. Bu bağlamda, deney numunelerinin mesnet bölgesinde ölçülen malzeme birim şekil değiştirmelerinin eğilme momenti talebi ile değişimi, Şekil 16 ve Şekil 17 'de, plastik mafsal davranış farklılığına göre karşılaştırılmıştır. Şekillerden de görüleceği üzere, yön değiştiren plastik mafsal davranışı sergileyen K3.6YP1 ve K6.0YP1 numunelerinde boyuna donatı oranı az olan kiriş yüzünün çekmeye zorlandığ $1(\mathrm{M}<0)$ elastik ötesi davranışta hasar, donatı kontrollü sınır durumla gerçekleşmektedir. Donatı oranının azalmasıyla -kuvvet dengesi gereği- tarafsız eksen derinliğinin küçüleceği ve dolayısıyla çekme donatısındaki birim uzamanın artacağından hareketle bu eğilim doğal karşılanabilir. K3.6YP1 ve K6.0YP1 numunelerinde boyuna donatı oranı yüksek olan kiriş yüzünü çekmeye zorlayan $\left(\rho^{\prime} / \rho=0.5, M>0\right)$ elastik ötesi davranışta, basınç donatılarının burkulmasıyla en dış beton lifindeki birim kısalmada bir sıçrama gözlenmekte ve beton birim kısalması sargılı beton ezilme birim kısalmasının üzerine çıkmaktadır. Bu davranış, özellikle yanal donatı aralığı Türk Deprem Yönetmeliği [2] sınırlamalarını karşılamayan ( $\mathrm{s}_{\mathrm{e}} / \phi_{\text {boyuna }}=12.5$ ) 
K6.0YP1 numunesinde daha belirgin olarak gözlenmektedir. Boyuna donatıdaki burkulma öncesi sargılı beton basınç lifi birim şekil değiştirme istemi, örtü betonu ezilme birim kısalmasına yakınken, donatı burkulmasını takip eden yükleme çevrimi içinde sargılı beton birim kısalma isteminde ani bir sıçrama gerçekleşmekte ve ezilme meydana gelmektedir.

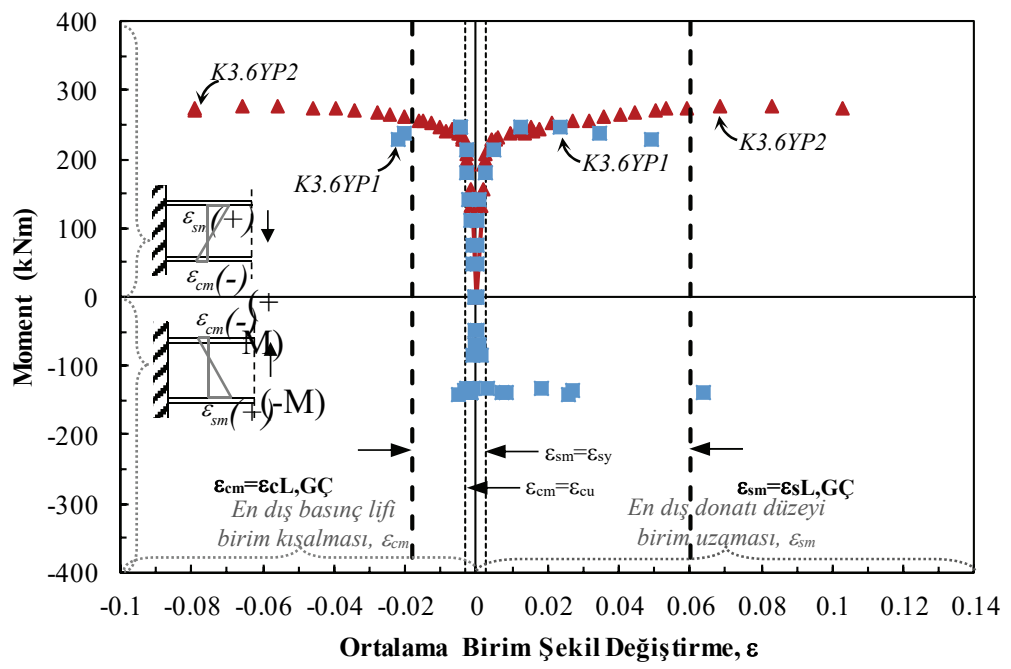

Şekil 16 - K3.6YP1 ve K3.6YP2 numunelerinde deneysel moment-malzeme birim şekil değiştirme ilişkileri

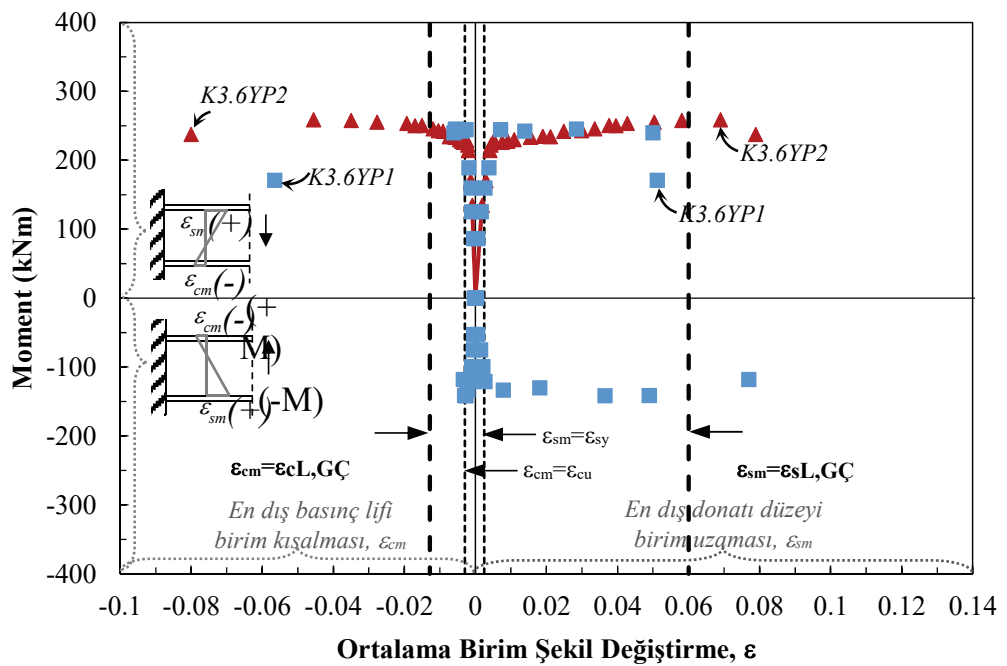

Şekil 17 - K6.0YP1 ve K6.0YP2 numunelerinde deneysel moment-malzeme birim şekil değiştirme ilişkileri 
K3.6YP1 numunesi yanal donatı aralığ1 bakımından $\left(\mathrm{s}_{\mathrm{e}} / \phi_{\text {boyuna }}=8.0\right)$ Türk Deprem Yönetmeliği [2] sınırlarını sağlamakla beraber, benzer durum -daha sınırlı miktarda olmakla birlikte- söz konusudur. Tek yönlü plastik davranış sergileyen K3.6YP2 ve K6.0YP2 numunelerinin malzeme birim şekil değiştirmelerinin, çift yönlü plastik mafsal oluşumu gözlenen kontrol numunelerinin birim şekil değiştirmelerinin üzerinde olduğu söylenebilir.

Bilindiği gibi tersinir ve çevrimsel yükler altında zorlanan taşıyıcı elemanların yükyerdeğiştirme ilişkileri altında kalan alanların toplamı, birikimli sönümlenen enerji olarak tanımlanır. Deney programında YP1 ve YP2 isimli iki farklı yükleme geçmişinin uygulandığı özdeş deney numuneleri için güç tükenmesi durumundaki sönümlenen enerji kapasiteleri, Şekil 18 üzerinde karşılaştırılmıştır. Karşılaştırmalarda, deney numunelerinin yükyerdeğiştirme ilişkileri üzerinde işaretlenen 3 farklı hasar durumuna (donatıda akma, örtü betonda ezilme başlangıcı ve boyuna donatıda burkulma hasar durumları) karşı gelen birikimli sönümlenen enerji değerleri de işaretlenerek, farklı hasar durumlardaki enerji kapasitelerinin kıyaslanması amaçlanmıştır.

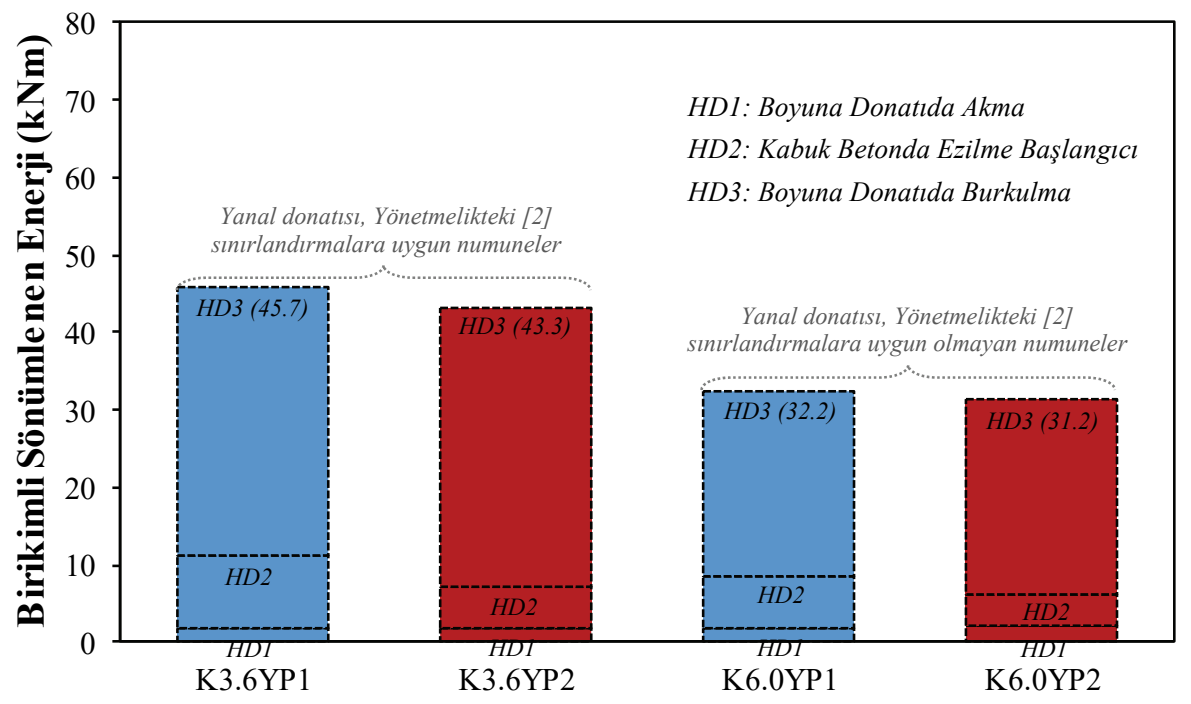

De ney Numunesi

Şekil 18 - YP1 ve YP2 yükleme geçmişlerinin uygulandı̆̆ numunelerde güç tükenmesi durumunda birikimli sönümlenen enerji kapasitelerinin karşılaştırılması

Şekil 18'de çevrim sayısından bağımsız olarak yapılan karşılaştırmalardan da görüleceği gibi, YP1 yükleme geçmişinin uygulandığı numunelerde, farklı hasar durumlarına karşı gelen sönümlenen enerji kapasitelerinin, YP2 yükleme geçmişinin uygulandığ numunelerin enerji kapasitesine kıyasla; bir miktar büyük olmakla birlikte, yaklaşık olarak eşit olduğu söylenebilir. Buna karşın, yönetmelikte [2] verilen yanal donatı aralık sınırlarını karşılayan ve karşılamayan numuneler, yükleme geçmişi farklarına göre hasar durumu açısından kıyaslandıklarında, birikimli sönümlenen enerji kapasiteleri arasındaki farklılığın daha belirgin düzeyde olduğu söylenebilir. 


\section{DENEYSEL VE ANALITIKK GÖÇME HASAR SINIR DURUMLARININ KARŞILAŞTIRILMASI}

Performansa dayalı tasarıma yönelik dokümanlarda tanımlanan hasar seviyelerinin nicel ifadesi olarak, sünek taşıyıcı sistem elemanları için plastik şekil değiştirme sınırları kullanılır. Çeşitli tasarım yönetmeliklerinde [2, 3, 19 ve 20] tanımlanan göçme hasar sınırı yer değiştirmelerinin, deneysel sonuçlar ile karşılaştırılması, Şekil 19 ve Şekil 20'da verilen diyagramlar üzerinde özetlenmiştir.

Şekil 19'dan da görüleceği gibi, yön değiştiren plastik mafsal davranışı sergileyen deney numuneleri için, Eurocode-8 [3] ve FEMA-356 [19] yönetmeliklerince tanımlanan analitik göçme yer değiştirme sınırları, deneysel sonuçlara oldukça yakındır. Yeni Zelanda Betonarme Yapı Standardının (NZS-3101) [20] analitik göçme sınırı tahminleri -elemanın süneklik düzeyine bağlı olması nedeniyle- yanal donatısı sık ve a/d oranı 3.6 olan numunede kapasitenin bir miktar üzerinde, yanal donatısı seyrek ve a/d oranı 6.0 olan numunede ise bir miktar altındadır. Türk Deprem Yönetmeliğinde göçme hasar sınırı için verilen ve yanal donatıya bağlı sargılı beton birim şekil değiştirme sınırı ile belirlenen yer değiştirme kapasitesinin -özellikle yanal donatısı seyrek numunede- deneysel kapasitenin üzerinde olduğu söylenebilir.
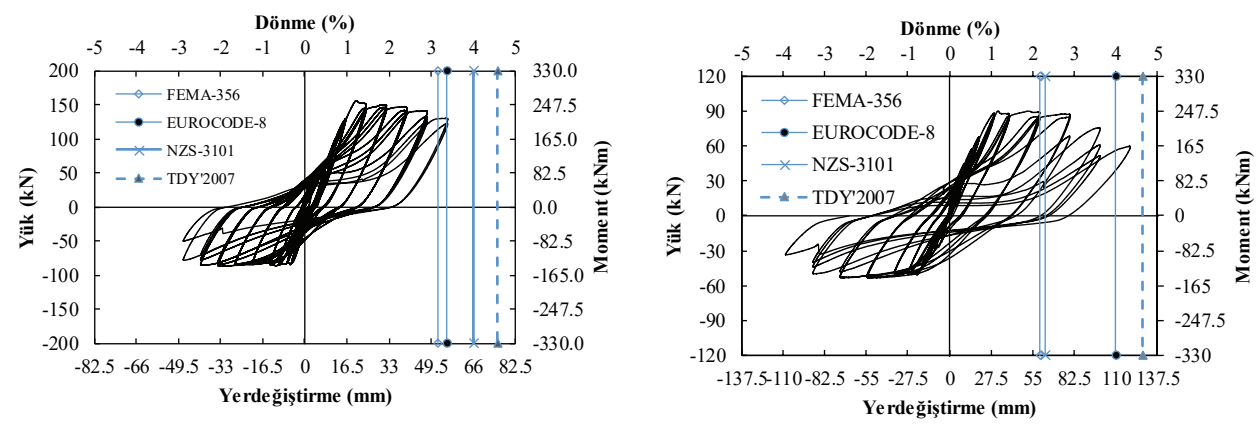

Şekil 19 - K3.6YP1 (sol) ve K6.0YP1 (să̆) numunelerinde analitik göçme sınırı tahminlerinin deneyse sonuçlar ile karşılaştırılması
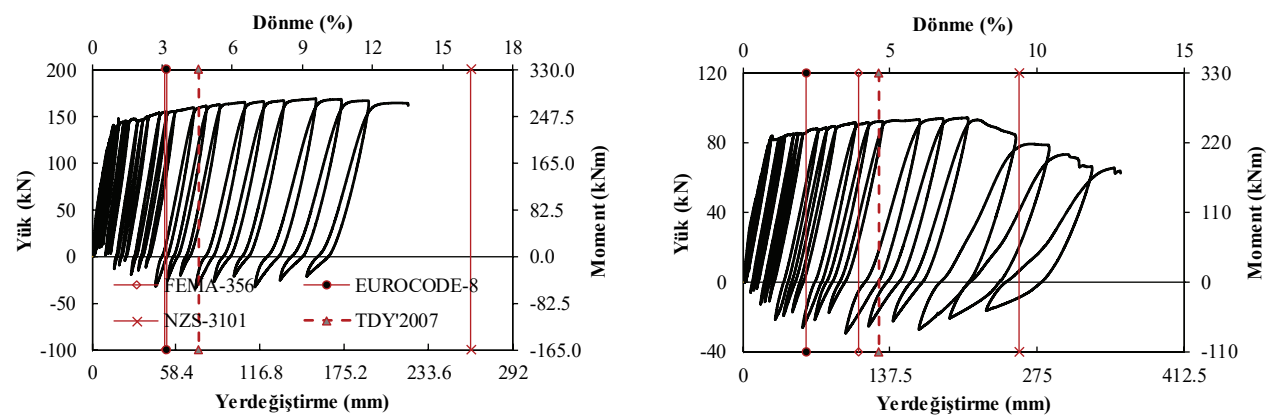

Şekil 20 - K3.6YP2 (sol) ve K6.0YP2 (să̆) numunelerinde analitik göçme sınırı tahminlerinin deneyse sonuçlar ile karşılaştırılması 
Şekil 20'de verilen karşılaştırmalardan da görüleceği üzere, kritik kesitinde yön değiştirmeyen plastik mafsal davranışı söz konusu olan deney numuneleri için Eurocode-8, FEMA-356 ve Türk Deprem Yönetmeliğinin analitik göçme hasar sınırı tahminleri, deneysel sonuçlara göre ihtiyatlı kalmaktadır. NZS-3101 yönetmeliğinin analitik göçme sınırı tahminleri ise -yönetmelik tahmininin, tek ya da çift yönlü plastik mafsal durumu ve süneklik düzeyine bağlı değişmesi nedeniyle- yanal donatısı sık ve a/d oranı düşük olan numunede kapasitenin bir miktar üzerinde; yanal donatısı seyrek ve a/d oranı ise yüksek numunede ise başarılı olduğu söylenebilir.

Türk Deprem Yönetmeliğinin göçme sınırı yer değiştirme kapasitesi tahminleri tek yönlü plastik mafsal davranışı durumunda deneysel kapasitenin altında, çift yönlü plastik mafsal oluşumu durumunda ise deneysel kapasitenin üzerinde sonuçlar verebilmektedir. Yönetmelikte malzeme birim şekil değiştirme üst limitlerine göre tanımlanan Göçme Sınırı Hasar durumunun, aşağıda maddeler halinde verilen öneriler dikkate alınarak geliştirilebileceği değerlendirilmektedir:

- Göçme hasarı için Türk Deprem Yönetmeliğinde [2] sargılı beton basınç lifi için tanımlanan malzeme birim şekil değiştirme ifadesi, basınç bölgesindeki boyuna donatılarda burkulma durumu için tanımlanacak bir üst değer ile sınırlandırılabilir (basınç donatısının beton basınç lifine yakınlığı gözetilerek). Çalışmada basınç donatısı burkulma birim şekil değiştirme sınırının ifade edilmesinde, Aydemir ve Eser [24] tarafından geliştirilen ve basınç etkisi altındaki donatı davranışının araştırıldığı geniş bir deneysel çalışma [25] sonuçlarının kullanıldığı bağıntılardan yararlanılacaktır. Sözü edilen bağıntılar $\mathrm{f}_{\mathrm{su}} / \mathrm{f}_{\mathrm{y}} \approx 1.3 \mathrm{kabul}$ edilerek, daha sade bir şekilde aşağıdaki gibi yazılabilir.

$$
\begin{aligned}
& \frac{s}{\phi_{b}} \geq 9, \quad \varepsilon_{s, L(\% 5)}^{\prime}=\varepsilon_{s y}^{\prime}+0.02 \cdot e^{\left(1.42-0.33 \cdot \frac{s}{\phi_{b}}\right)} \\
& 6 \leq \frac{s}{\phi_{b}}<9, \varepsilon_{s, L(\% 5)}^{\prime}=\varepsilon_{s y}^{\prime}+0.06 \cdot e^{\left(5-0.86 \cdot \frac{s}{\phi_{b}}\right)}
\end{aligned}
$$

(3) bağıntısında, $\varepsilon_{\mathrm{s}}{ }^{\prime}(\% 5)$, basınç donatısı gerilmesinin akma gerilmesinin \%95'ine düştüğü duruma karşı gelen birim şekil değiştirme sınırını, $\varepsilon_{\text {sy }}^{\prime}$, basınç donatısı akma birim şekil değiştirmesini ve $\mathrm{s} / \phi_{\mathrm{b}}$ ise burkulma boyunun, boyuna donatı çapına oranını göstermektedir. Bağıntıda yer alan burkulma boyunun (s), etriye aralığına ( $\mathrm{s}_{\mathrm{e}}$ ) bağlı bir biçimde belirlenmesinde, Aydemir ve Eser [21] tarafından enerji esaslı bir yöntem kullanılarak [26] geliştirilen bir bağıntıdan yararlanılacaktır.

$$
\frac{s}{s_{e}}=0.7+\frac{0.24}{\zeta} \geq 1, \quad \zeta=\frac{32 \cdot \frac{A_{s h}}{d_{h}} \cdot\left(\frac{s_{e}}{\phi_{b}}\right)^{2} \cdot s_{e}}{\pi^{4} \cdot A_{s}^{\prime} \cdot \sqrt{\frac{f_{y}}{400}}}
$$


(4) bağıntısında, $A_{\text {sh }}$, göz önüne alınan eğilme doğrultusundaki yanal donatı kollarının en kesit alanları toplamı, $\phi_{b}$, göz önüne alınan eğilme doğrultusundaki basınç donatısı minimum çapı, $\mathrm{S}_{\mathrm{e}}$, yanal donatı aralığı, $\mathrm{A}_{\mathrm{s}}{ }^{\prime}$ göz önüne alınan eğilme doğrultusundaki basınç yüzü donatılarının en kesit alanı toplamı, $f_{\mathrm{y}}$, donatı akma dayanımıdır. Burkulma boyunun belirlenmesinde kullanılan $\xi$ parametresinin ifade edildiği bağıntıda, pay ve payda $\left(b_{\mathrm{w}} \times \mathrm{d}\right)$ 'ye bölünüp, $\mathrm{f}_{\mathrm{y}}=420 \mathrm{MPa}, \mathrm{d}_{\mathrm{h}} \approx 0.98 \times \mathrm{d}$ kabulleri ve $\rho_{\mathrm{w}}=\mathrm{A}_{\mathrm{sh}} /\left(\mathrm{s}_{\mathrm{e}} \times \mathrm{b}_{\mathrm{w}}\right)$, $\rho^{\prime}=\mathrm{A}^{\prime} /\left(\mathrm{b}_{\mathrm{w}} \times \mathrm{d}\right)$ kısaltmalarıyla, burkulma boyu ifadesi daha sade bir biçimde aşağıdaki (5) bağıntısıyla da ifade edilebilir.

$$
\frac{s}{s_{e}}=0.7 \times\left\{1+\left(1.05 \times \rho^{\prime}\right) /\left[\left(\rho_{s} \times\left(\frac{s_{e}}{\varphi_{b}}\right)^{2} \times\left(\frac{s_{e}}{d}\right)^{2}\right)\right]\right\} \geq 1,
$$

Yukarıda tanımlanan basınç donatısı burkulma birim şekil değiştirme sınırı yardımıyla, Türk Deprem Yönetmeliğindeki Göçme Hasar Sınırı sargılı beton birim şekil değiştirmesi, sargı koşullarını sağlayan ve sağlamayan elemanlar için aşağıdaki bağıntılar ile ifade edilebilir.

Türk Deprem Yönetmeliğinde verilen sargı koşullarını sağlamayan kirişlerde;

$$
\left(\varepsilon_{c g}\right)_{G C}=0.004+0.014 \times \frac{\rho_{s}}{\rho_{s m}} \leq \varepsilon_{s, L(\% 5)}^{\prime}
$$

Türk Deprem Yönetmeliğinde verilen sargı koşullarını sağlayan kirişlerde;

$$
\left(\varepsilon_{c g}\right)_{G C}=0.018 \leq \varepsilon_{s, L(\% 5)}^{\prime}
$$

Şekil 21'de basınç bölgesinde hasarın betimlenmesinde kullanılan malzeme birim şekil değiştirme sınırları, aynı diyagram üzerinde gösterilmiştir. Şekilden de görüleceği üzere, donatının 1. mod şekline uygun burkulması ve etriye aralığının basınç donatısı çapının 7 katının üzerinde olması halinde, sargılı beton ve basınç donatısı birim şekil değiştirme sınırları arasında farklılık belirginleşmektedir. Aynı burkulma şeklinde, etriye aralığının basınç donatısı çapının 7 katı ve altında olması durumlarında ise malzeme birim kısalması 0.018 'dir. Şekilde kesikli çizgi ile gösterilen donatı birim şekil değiştirme sınırı, donatı burkulma boyunun etriye aralığının iki katına eşit alındığı burkulma şekline karşı gelmektedir. Bu burkulma şekli, basınç yüzündeki donatı miktarının yüksek olduğu, etriye aralığının sık, etriye çapı ve kol sayısının az olduğu durumlarda oluşabilir.

- Çift yönlü plastik davranış sergileyen kirişlerin Göçme Sınırı Hasar yerdeğiştirme kapasitelerinin belirlenmesinde $\mathrm{L}_{\mathrm{p}} \approx 0.5 \mathrm{~h}$ alınabilir [2].

- Tek yönlü plastik davranış sergileyen kirişlerin Göçme Sınırı kesit eğrilikleri ve plastik mafsal boyları, çift yönlü plastik davranış kabullerine göre belirlenen değerlerin 2 katı alınabilir $[16,20]$. 
Yukarıda maddeler halinde açıklanan yaklaşımın sonuçlarının, deneysel sonuçlar ile karşılaştırılması Şekil 22 ve 23'de gösterilmiştir. Önerilen yöntemin literatürdeki çeşitli deneysel çalışmaların sonuçlarıyla karşılaştırılması da Çizelge $3^{\prime}$ de özetlenmiştir. Sınırlı sayıda numune ile yapılan bu karşılaştırma sonuçlarından da görüleceği üzere, tek ya da çift yönlü plastik mafsal oluşumu durumlarında önerilen yöntemle belirlenen analitik hasar sınırı yer değiştirme kapasiteleri, deneysel sonuçlara yakın sonuçlar vermektedir.

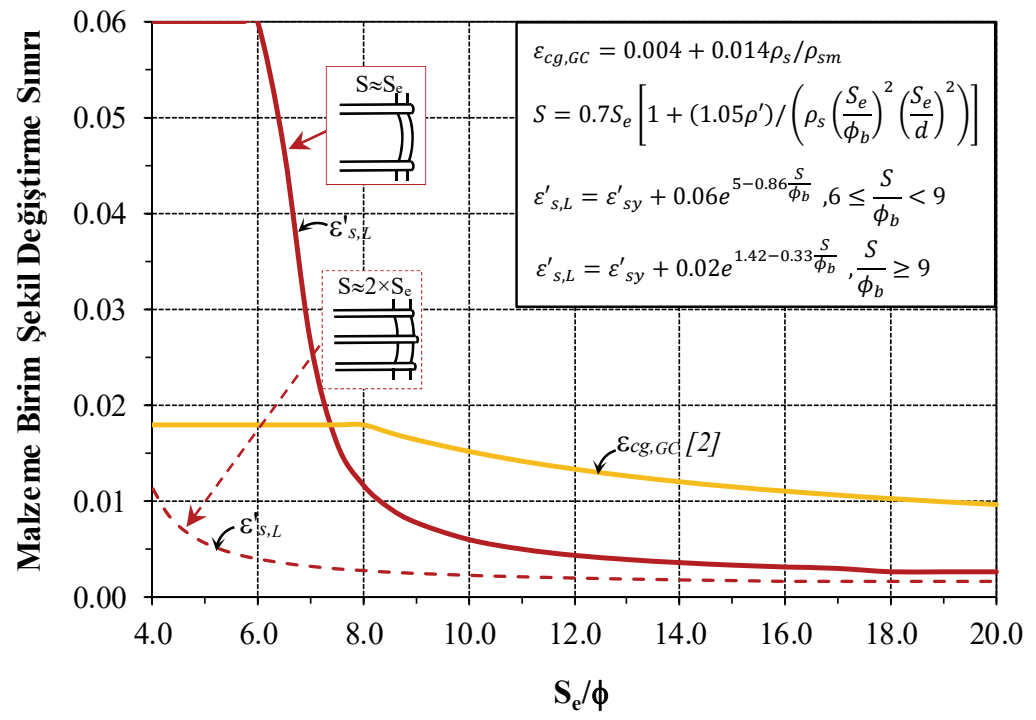

Şekil 21 - Göçme hasar sınırı durumunda sargılı beton lifi ve basınç donatısı malzeme şekil değiştirme sınırlarının $s_{e}$ / $\phi$ oranı ve burkulma boyuna göre değişimleri
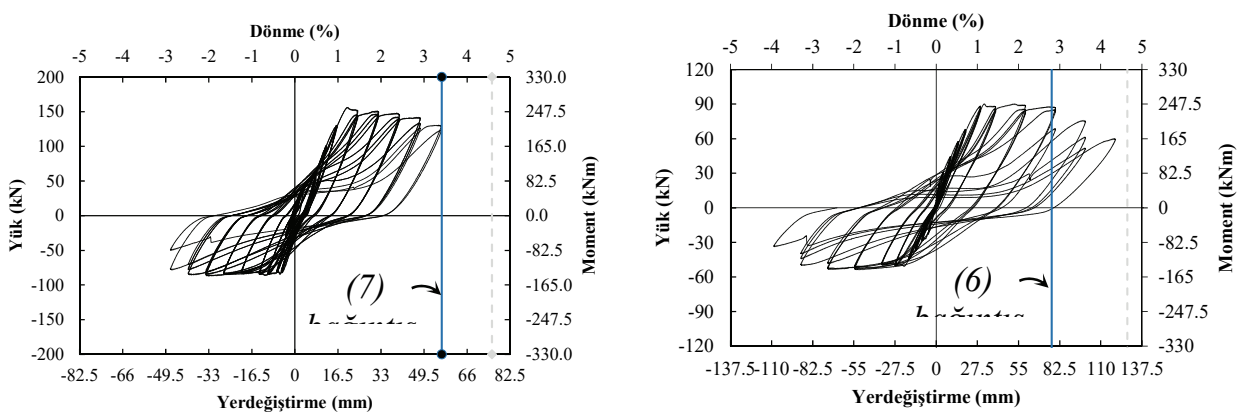

Şekil 22 - K3.6YP1 (sol) ve K6.0YP1 (săg) numunelerinde önerilen yöntemle belirlenen analitik gö̧̧me hasar sınırı yer değiştirme kapasitelerini deneysel sonuçlar ile karşılaştırılması 

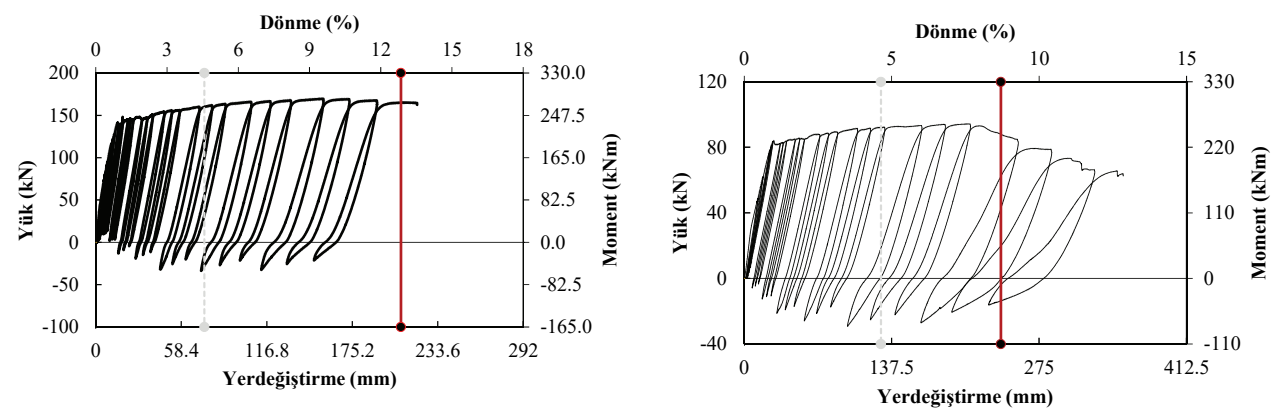

Şekil 23 - K3.6YP2 (sol) ve K6.0YP2 (săg) numunelerinde önerilen yöntemle belirlenen analitik göçme hasar sınırı yer değiştirme kapasitelerini deneysel sonuçlar ile karşılaştırılması

Çizelge 3 - Önerilen Göçme Hasar Sınırı yaklaşımının, literatürdeki deneysel sonuçlarla karşılaştırılması

\begin{tabular}{|c|c|c|c|c|c|c|c|}
\hline $\begin{array}{l}\text { Referans/ } \\
\text { Numune }\end{array}$ & $\begin{array}{c}\mathrm{b} / \mathrm{h} \\
(\mathrm{cm} / \mathrm{cm})\end{array}$ & $\begin{array}{c}\mathrm{f}_{\mathrm{c}} \\
(M P a)\end{array}$ & $\begin{array}{c}\mathrm{f}_{\mathrm{y}} \\
(M P a)\end{array}$ & $\begin{array}{l}\text { Boyuna donat1 } \\
\text { (Ü: üst/A: Alt) }\end{array}$ & $\begin{array}{c}\text { Enine } \\
\text { Donat1 } \\
(\phi / s)\end{array}$ & $\begin{array}{c}\Delta_{\text {maks,deneysel }} \\
\quad(\mathrm{mm})\end{array}$ & $\begin{array}{c}\Delta_{\text {maks,önerilen }} \\
(\mathrm{mm})\end{array}$ \\
\hline$[16] / A 1^{*}$ & $25 / 40$ & 41.8 & 350 & $\ddot{U}: 3 \phi 25 / \mathrm{A}: 3 \phi 25$ & $10 / 17.5$ & 42.6 & 54.9 \\
\hline$[16] / A 2^{*}$ & $25 / 40$ & 41.8 & 350 & Ü:3ф25/A:3ф25 & $10 / 10$ & 56.8 & 57.6 \\
\hline$[16] / \mathrm{Cl}^{*}$ & $25 / 40$ & 27.4 & 350 & Ü:5 $525 / \mathrm{A}: 2 \phi 16$ & $10 / 13$ & 35.5 & 24.6 \\
\hline$[\mathbf{1 6}] / \mathrm{C} 2^{* *}$ & $25 / 40$ & 27.4 & 350 & $\ddot{U}: 5 \phi 25 / \mathrm{A}: 2 \phi 16$ & $10 / 13$ & 78.1 & 79.3 \\
\hline$[16] / D 1^{*}$ & $41 / 40$ & 25.6 & 570 & $\ddot{U}: 3 \phi 16 / A: 3 \phi 16$ & $10 / 17.5$ & 49.7 & 40.9 \\
\hline$[16] / D 2^{* *}$ & $41 / 40$ & 25.6 & 570 & 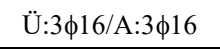 & $10 / 17.5$ & 142 & 135.5 \\
\hline$\left[\mathbf{1 7 ]} / \mathrm{VR} 1^{*}\right.$ & $25 / 50$ & 41.7 & 473 & $\ddot{\mathrm{U}} 44 \phi 16^{* * *} / \mathrm{A}: 2 \phi 16$ & $10 / 15$ & 26.5 & 25.9 \\
\hline$[17] / V R 2^{* *}$ & $25 / 50$ & 44.8 & 473 & 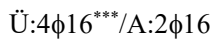 & $10 / 15$ & 87 & 83.5 \\
\hline
\end{tabular}

\section{SONUÇLAR VE ÖNERİLER}

$\mathrm{Bu}$ çalışmada, tersinir-çevrimsel yüklemeler altında zorlanan kirişlerde yön değiştiren ve değiştirmeyen plastik mafsal davranış biçimleri deneysel olarak incelenmiştir. Deney programında, plastik mafsal davranış biçimindeki farklılığın; kesit eğriliği, plastik mafsal boyu ve göçme sınırı yer değiştirme kapasitesi üzerindeki etkileri karşılaştırmalı olarak irdelenmiştir. Sınırlı sayıda deney numunesi sonucu esas alınarak yapılan karşılaştırmalardan elde edilen temel sonuçlar aşağıda maddeler halinde sunulmuştur.

- Deprem etkisinde kiriş ekseni boyunca sabit olan kesme kuvveti, sadece düşey işletme yüklerinden oluşan tesirlerin, depremli durumdaki tasarım değerine kıyasla belirgin mertebede olması durumunda işaret değiştirebilir. Çerçeve kirişlerinde kesme kuvvetinin 
işaret değişimi, negatif eğilmeye zorlanan kiriş mesnet kesitinde maksimum eğilme momentinin (plastik mafsal momenti) kolon yüzünde oluşmasına, pozitif eğilmeye zorlanan kiriş mesnet bölgesinde ise maksimum eğilme momentinin mesnetten açıklık bölgesine doğru kaymasına neden olur (Bkz. Şekil 2). Bu durumda çerçeve kirişlerinde meydana gelecek tek yönlü (yön değiştirmeyen) plastik mafsal oluşumu, kirişin kapasite tasarımı hesap esaslarını, boyuna ve enine donatıların detaylandırılması gibi çeşitli hususlar üzerinde değişkenlik yaratabilir.

- Yön değiştirmeyen plastik mafsal davranışının gözlendiği deney numunelerinin plastik dönme kapasiteleri, çift yönlü plastik mafsal davranışı gözlenen deney numunelerinin plastik dönme kapasitelerinin üzerindedir (Bkz. Şekil 8 11). Benzer eğilim, plastik mafsal boyu ve toplam kesit eğriliği için de söylenebilir. Göçme Hasar Sınırı için tek yönlü plastik mafsal durumundaki kesit eğriliği ve plastik mafsal boyları, çift yönlü plastik mafsal davranış durumundaki kesit eğriliği ve plastik mafsal boyunun yaklaşık 2 katı üzerinde gerçekleşmiştir (Bkz. Şekil 13 15).

- Çalışmada, plastik mafsal davranış biçimindeki değişkenliğin, Türk Deprem Yönetmeliğinde göçme hasar sınırına karşı gelen yer değiştirme sınırı hesaplarında dikkate alınabilmesi için bazı önerilerde bulunulmuştur. Basınç bölgesinde donatı birim kısalma sınırı, yön değiştirmeyen plastik mafsal davranışında kesit eğriliği ve plastik mafsal boyu varsayımlarında yapılan önerilerle belirlenen analitik değerler; sınırlı sayıdaki numunelerin deneysel sonuçlarıyla karşılaştırılmış ve genelde iyi sonuçlar verdiği görülmüştür. (Bkz. Şekil 22 ve Çizelge 3).

- Deney programında konsol kiriş şeklinde uygulanan test düzeni ve deney numunelerinin çift donatılı dikdörtgen kesitli alınabileceği varsayımı, davranışı çok etkilemeyeceği düşünülen basitleştirici kabullerdir. Bununla birlikte, konunun derinleştirilmesi (kiriş mekanizma durumu incelemeleri vb.) amacıyla gelecekte yapılacak çalışmalarda, çerçeve türü bir yapısal sistemin incelenmesi ve kiriş kesitlerinde tabla betonu ve donatısının bulundurulması önerilmektedir. Ayrıca çalışmada uygulanan işletme yükü kısa süreli yük olarak uygulanmış ve zamana bağlı muhtemel değişimler gözlenememiştir. İşletme yükü tesirinin belirgin mertebede olması ve özellikle basınç bölgesinde beton dayanımının düşük ya da basınç donatısı miktarının az olmasına bağlı olarak, zamana bağlı ilave şekil değiştirmelerin davranış üzerinde etkileri ayrıca incelenmelidir.

\section{Semboller}

a $\quad$ Kirişin kesme açıklığ 1

$\mathrm{A}_{\mathrm{sh}} \quad$ : Kesme donatısı toplam kesit alanı

$\mathrm{A}_{\mathrm{s}}{ }^{\prime} \quad$ : Basınç donatısı kesit alanı

b : Kesit genişliği

d : Kesitin etkili derinliği

$\mathrm{d}_{\mathrm{h}} \quad$ : yanal donatının mesnet oluşturduğu boyuna donatı eksenleri arası mesafe (h-2 $\left.\mathrm{d}^{\prime}\right)$

$f_{\mathrm{c}} \quad$ : Beton basınç dayanımı 
$f_{\mathrm{y}} \quad$ : Donatı akma dayanımı

$f_{\mathrm{yw}} \quad$ : Sarg1 donatısı akma dayanımı

$f_{\text {su }} \quad$ : Donatı çeliği çekme dayanımı

h $\quad$ : Kesit yüksekliği

L : Kiriş boyu

$\mathrm{L}_{\mathrm{p}} \quad$ : Plastik mafsal boyu

$\mathrm{L}_{\mathrm{p}, \text { ort }} \quad$ : Ortalama eşdeğer plastik mafsal boyu

$\mathrm{M}_{\text {maks }} \quad$ : Deneysel eğilme momentinin maksimum değeri

$\mathrm{M}_{\mathrm{n}} \quad$ : Deneysel malzeme dayanımları kullanılarak belirlenen eğilme dayanımı

S : Burkulma boyu

$\mathrm{S}_{\mathrm{e}} \quad$ : Plastik mafsal kesiminde yanal donatı aralığ

$\mathrm{V}_{\text {maks }} \quad$ : Deneysel kesme kuvvetinin maksimum değeri

$\mathrm{V}_{\mathrm{s}} \quad$ : Yanal donatının kesme dayanımına katkısı

$\Delta \quad$ : Tepe yer değiştirmesi

$\Delta_{\mathrm{e}} \quad$ : Elastik yer değiştirme

$\Delta_{\mathrm{p}} \quad$ : Plastik yer değiştirme

$\varepsilon_{0} \quad$ : Kiriş ekseni boyunca farklı gözlem aralıklarından ölçülen eğilmeden kaynaklı yerdeğiştirme farklarına göre belirlenen, en dış beton yüzü $\left(\varepsilon_{\mathrm{cm}}\right)$ ya da en diş donatı seviyesindeki $\left(\varepsilon_{\mathrm{cm}}\right)$ ortalama birim şekil değiştirme.

$\varepsilon_{\mathrm{cg}} \quad$ Göçme hasar sınırı sargılı beton birim kısalma üst değeri

$\varepsilon_{\mathrm{cu}} \quad:$ TS500-2000'de verilen sargisız beton etkili birim kisalması (0.003)

$\varepsilon_{\mathrm{sy}} \quad$ : Donatı çeliği akma birim şekil değiştirmesi

$\varepsilon_{\mathrm{sL}} \quad$ : Belirli bir hasar sınırında donatı çeliği birim uzama değeri

$\varepsilon_{\mathrm{s}^{\prime} \mathrm{L}} \quad$ : Burkulma hasar sınırı için donatı çeliği birim kısalma sınır değeri

$\phi \quad$ : Kesit eğriliği

$\phi_{\mathrm{b}} \quad$ : Kesitin basınç yüzündeki en küçük donatı çapı

$\phi_{\mathrm{L}} \quad$ : Belirli bir hasar sınırı için toplam kesit eğriliği

$\phi_{\mathrm{p}} \quad$ : Plastik Kesit eğriliği

$\phi_{\mathrm{y}} \quad$ : Akma eğriliği

$\theta_{\mathrm{p}} \quad$ : Plastik dönme

$\theta_{\mathrm{p}, \mathrm{L}} \quad$ : Belirli bir hasar sınırı için plastik dönme 


$\begin{array}{ll}\rho & : \text { Çekme donatısı oranı } \\ \rho_{\mathrm{s}} & : \text { Yanal donatı oranı } \\ \rho_{\mathrm{sm}} & : \text { Minimum yanal donatı oranı } \\ \rho^{\prime} & : \text { Basınç donatısı oranı }\end{array}$

\section{Teşekkür}

Bu çalışma, İstanbul Aydın Üniversitesi Bilimsel Araştırma Projeleri Koordinatörlüğü’nce BAP2016-01 nolu proje kapsamında desteklenmiştir. Proje çalışmasında değerli emekleri olan Prof. Dr. Metin GER'e, ayrıca deneylerin gerçekleştirilmesine katkı sağlayan Prof. Dr. Güray ARSLAN'a (YTÜ), İstanbul Aydın Üniversitesi İnşaat Mühendisliği Laboratuvarı teknik ekibine ve UTEST'e teşekkürlerimizi sunarız.

\section{Kaynaklar}

[1] Betonarme Yapıların Hesap ve Yapım Kuralları, TS-500, Türk Standartları Enstitüsü, Ankara, 2000.

[2] Deprem Bölgelerinde Yapılacak Binalar Hakkında Yönetmelik, Bayındırlık ve İskân Bakanlığı, Ankara, Mart 2007.

[3] EN 1998-3, Eurocode 8: Design of Structures for Earthquake Resistance-Part 3: Assessment and Retrofitting of Buildings, Brussels, 2003.

[4] Corley, G. W., Rotational Capacity of Reinforced Concrete Beams, Journal of the Structural Division, ASCE, V. 92, 121-146, 1966

[5] Baker, A. L. L., and Amarakone, A. M. N., Inelastic Hyperstatic Frame Analysis, Flexural Mechanics of Reinforced Concrete, ACI, SP-12, 85-142, 1967.

[6] Mattock, A. H., Rotational Capacity of Hinging Regions in Reinforced Concrete Beams, Flexural Mechanics of Reinforced Concrete, ACI, SP-12, 143-181, 1967.

[7] Eligehausen, R., and Langer, P., Rotation Capacity of Plastic Hinges and Allowable Moment Redistribution, CEB Bulletin, No. 175, I7.9-I7.27, 1987.

[8] Hillerborg, A., Fracture Mechanics Concepts Applied to Moment Capacity and Rotational Capacity of Reinforced Concrete Beams, Engineering Fracture Mechanics, V. 35, 233-240, 1990.

[9] Bigaj, A. J., Structural Dependence of Rotation Capacity of Plastic Hinges in RC Beams and Slabs, PhD thesis, Delft University, the Netherlands, 1999.

[10] Bigaj, A. J., and Walraven, J., Size Effects on Plastic Hinges of Reinforced Concrete Members, Heron, V. 47, 53-75, 2002.

[11] Ma, S.Y.M., Bertore, V.V, and Popov, E.P., Experimental and Analytical Studies On Hysteretic Behavior of Reinforced Concrete Rectangular and T-Beams, Report EERC 76-2, University of California, Berkeley, May 1976, 241 pages. 
[12] ECCS, Recommended testing procedure for assessing the behaviour of structural steel elements under cyclic loads, European Convention for Constructional Steelwork, 1985.

[13] ACI T1.1-01, Acceptance criteria for moment frames based on structural testing, ACI, 2001.

[14] ATC Report No. 24, Guidelines for seismic testing of components of steel structures, ATC, 1992.

[15] Megget, L. M. and Fenwick, R. C., Seismic behaviour of a reinforced concrete portal frame sustaining gravity goads, Bulletin of NZ Society for Earthquake Engineering, Vol. 22, No. 1, 1989.

[16] Walker A.F., and Dhakal R.P., Assessment of material strain limits for defining plastic regions in concrete structures, Bulletin of The New Zealand Society for Earthquake Engineering, Vol. 42, No. 2, 2009.

[17] Gião R., Lúcio V., and Chastre C., Assessing the behaviour of RC beams subject to significant gravity loads under cyclic loads, Engineering Structures, Vol. 59, 512-21, 2014.

[18] Kaya E., Kütan C., Sheikh S., and İlki A., Flexural Retrofit of Support Regions of Reinforced Concrete Beams with Anchored FRP Ropes UsingNSM and ETS Methods under Reversed Cyclic Loading, J. Compos. Constr., 21(1), 2017.

[19] Federal Emergency Management Agency, Prestandard and commentary for the seismic rehabilitation of buildings, Washington (DC): FEMA-356, 2000.

[20] SANZ Concrete Structures Standard, NZS 3101:2006. Standards Association, Wellington, NZ, 2006.

[21] Ersoy U., Betonarme Kiriş ve Kolonların Moment Kapasitelerinin Saptanması, Teknik Dergi, 9(4), 1781-97, 1998.

[22] Aydemir C., Döşeme Donatılarının İç Aks Kirişlerinin Negatif Moment Kapasitesi Üzerine Etkisi, Teknik Dergi, 24(1), 6279-6306, 2013.

[23] Park, R., and Paulay, T., Reinforced Concrete Structures, John Wiley and Sons, New York, 1975.

[24] Aydemir C., ve Aydemir M.E., Betonarme Kirişlerin Hasar Sınırlarının Deneysel Gözlemlerle İrdelenmesi, Teknik Dergi, 28(4), 8023-49, 2017.

[25] Mieses, A.M., Inelastic Buckling Behavior of Concrete Reinforcing Bars under Monotonic Uniaxial Compressive Loading, M.S. thesis, The University of Texas at Austin, 2002

[26] Dhakal, R.P. and Maekawa, K., Reinforcement Stability and Fracture of Cover Concrete in Reinforced Concrete Members, Journal of Structural Engineering, ASCE, 128(10):1253-1262, 2002. 
